\title{
Ideas and perspectives: Carbon leaks from flooded land: do we need to replumb the inland water active pipe?
}

\author{
Gwenaël Abril ${ }^{1,2}$ and Alberto V. Borges ${ }^{3}$ \\ ${ }^{1}$ Biologie des Organismes et Ecosystèmes Aquatiques (BOREA), UMR 7208, Muséum National d'Histoire Naturelle, \\ CNRS, SU, UCN, UR, IRD, 61 rue Buffon, 75231, Paris CEDEX 05, France \\ ${ }^{2}$ Programa de Biologia Marinha e Ambientes Costeiros, Universidade Federal Fluminense, Outeiro São João Batista s/n, \\ 24020015, Niterói, RJ, Brazil \\ ${ }^{3}$ Université de Liège, Unité d’Océanographie Chimique, Institut de Physique (B5a), 4000 Liège, Belgium
}

Correspondence: Gwenaël Abril (gwenael.abril@mnhn.fr)

Received: 22 May 2018 - Discussion started: 30 May 2018

Revised: 29 December 2018 - Accepted: 19 January 2019 - Published: 12 February 2019

\begin{abstract}
At the global scale, inland waters are a significant source of atmospheric carbon $(\mathrm{C})$, particularly in the tropics. The active pipe concept predicts that $\mathrm{C}$ emissions from streams, lakes and rivers are largely fuelled by terrestrial ecosystems. The traditionally recognized $\mathrm{C}$ transfer mechanisms from terrestrial to aquatic systems are surface runoff and groundwater drainage. We present here a series of arguments that support the idea that land flooding is an additional significant process that fuels inland waters with $\mathrm{C}$ at the global scale. Whether the majority of $\mathrm{CO}_{2}$ emitted by rivers comes from floodable land (approximately $10 \%$ of the continents) or from well-drained land is a fundamental question that impacts our capacity to predict how these $\mathrm{C}$ fluxes might change in the future. Using classical concepts in ecology, we propose, as a necessary step forward, an update of the active pipe concept that differentiates floodable land from drained land. Contrarily to well-drained land, many wetlands (in particular riparian and littoral wetlands) combine strong hydrological connectivity with inland waters, high productivity assimilating $\mathrm{CO}_{2}$ from the atmosphere, direct transfer of litter and exudation products to water and waterlogged soils, a generally dominant allocation of ecosystem respiration (ER) below the water surface and a slow gas-exchange rate at the water-air interface. These properties force plants to pump atmospheric $\mathrm{C}$ to wetland waters and, when hydrology is favourable, to inland waters as organic $\mathrm{C}$ and dissolved $\mathrm{CO}_{2}$. This wetland $\mathrm{CO}_{2}$ pump may contribute disproportionately to $\mathrm{CO}_{2}$ emissions from inland waters, particularly in the tropics where $80 \%$ of the global $\mathrm{CO}_{2}$ emissions to the atmo-
\end{abstract}

sphere occur. In future studies, more care must be taken in the way that vertical and horizontal $\mathrm{C}$ fluxes are conceptualized along watersheds, and 2-D models that adequately account for the hydrological export of all $\mathrm{C}$ species are necessary. In flooded ecosystems, significant effort should be dedicated to quantifying the components of primary production and respiration by the submerged and emerged part of the ecosystem community and to using these metabolic rates in coupled hydrological-biogeochemical models. The construction of a global typology of wetlands that includes productivity, gas fluxes and hydrological connectivity with inland waters also appears necessary to adequately integrate continental $\mathrm{C}$ fluxes at the global scale.

\section{Introduction}

Continental surfaces play a major role on the present and past climates, in particular through the exchange of greenhouse gases (GHGs) such as carbon dioxide $\left(\mathrm{CO}_{2}\right)$ and methane $\left(\mathrm{CH}_{4}\right)$ with the atmosphere (Ciais et al., 2013). Conversely, the global climate affects the continental carbon $(\mathrm{C})$ budget, as biological productivity and the capacity of ecosystems to store $\mathrm{C}$ are influenced by temperature, rainfall and other climatic variables (Heimann and Reichstein, 2008; Reichstein et al., 2013). The continental $\mathrm{C}$ budget is in addition affected by direct human alterations such as deforestation and reforestation as well as other land use changes. On continents, the $\mathrm{C}$ cycle is tightly coupled to the water cycle, 
and $\mathrm{CO}_{2}$ and $\mathrm{CH}_{4}$ budgets strongly depend on how and how much water circulates through the plants, soil, groundwater and surface waters to the coastal ocean. Biogeochemical processes and fluxes in the critical zone, the permeable layer of the continents from the vegetation top to the aquifer bottom (Lin, 2010), have varied drastically at geological timescales (Knoll and James, 1987). Emissions of GHGs from continental ecosystems are expected to be highly sensitive to precipitation and hydrology in the future (Ciais et al., 2013). Water is necessary for plant photosynthesis; moisture strongly controls respiration in soils; and the presence of water promotes anaerobic conditions and $\mathrm{CH}_{4}$ production in wetlands, while soil desiccation promotes soil $\mathrm{CH}_{4}$ oxidation. Water also considerably contributes to continental $\mathrm{C}$ budgets because rivers transport $\mathrm{C}$ laterally, with $\mathrm{C}$ being later trapped in sediments, emitted as $\mathrm{CO}_{2}$ and $\mathrm{CH}_{4}$ to the atmosphere, or exported to the ocean (Garrels and Macknezie, 1971; Meybeck, 1982; Cole et al., 2007).

In terms of $\mathrm{CO}_{2}$ and $\mathrm{CH}_{4}$ fluxes, continental landscapes act as a heterogeneous mosaic, and some ecosystems store or emit more atmospheric $\mathrm{C}$ than others. Some small surfaces can behave as hotspots and disproportionately contribute to the total $\mathrm{C}$ mass balance at the regional, continental and global scales. Surface waters are recognized hotspots for $\mathrm{CO}_{2}$ and $\mathrm{CH}_{4}$ fluxes (Cole et al., 1994; Cole and Caraco, 2001; Bastviken et al., 2011; Raymond et al., 2013; Holgerson and Raymond, 2016). Natural surface waters include the open waters of lakes, reservoirs, streams, rivers and estuaries (approximately $3.5 \%$ of the continents) as well as intermittently flooded land, where a canopy of vegetation is active above the water and/or when water is temporarily absent: swamps, marshes and floodplains, also called wetlands, that occupy approximately $10 \%$ of the continents (Downing, 2009). In general, inland waters and wetlands show higher atmospheric $\mathrm{C}$ exchange rates per surface area than the surrounding land: wetlands are recognized for their high productivity, sedimentary organic carbon (OC) burial and $\mathrm{CH}_{4}$ emissions (Mitsch et al., 2013). Inland waters (rivers, streams, lakes and reservoirs) act as a very significant source of atmospheric $\mathrm{CO}_{2}$ at the global scale (Raymond et al., 2013).

Although the magnitude of $\mathrm{CO}_{2}$ outgassing from inland surface waters at the global scale is still subject to large uncertainties, there is consensus that the quantity of $\mathrm{C}$ exported from land to freshwaters $\left(1.9-3.2 \mathrm{PgC} \mathrm{yr}^{-1}\right)$ was larger than the $\mathrm{C}$ flux ultimately reaching the ocean $\left(0.9 \mathrm{PgC} \mathrm{yr}^{-1}\right.$, Fig. 1b). Cole et al. (2007) have conceptualized inland waters as an active pipe (Fig. 1b), receiving, processing, emitting and storing terrestrial $\mathrm{C}$ during its travel from land to the ocean, as opposed to a passive pipe that simply transports terrestrial C conservatively to the ocean (Fig. 1a), as generally assumed in earlier literature from the 1970s and 1980s (Garrels and Mackenzie, 1971; Meybeck, 1982). Since this definition, it has been assumed that most of the $\mathrm{C}$ emitted by inland waters was initially fixed upland by terrestrial vegetation, then transported from soils to aquatic systems with runoff and drainage, and finally emitted downstream as $\mathrm{CO}_{2}$ to the atmosphere. Because no satisfactory methods are available yet to estimate directly the flux of $\mathrm{C}$ across the land-water boundary (e.g. Deirmendjian et al., 2018), this flux is calculated as the sum of outgassing from inland waters, burial in freshwater and estuarine sediments, and export to the coastal ocean (Cole et al., 2007). However, the processes controlling $\mathrm{C}$ fluxes at the land-water interface are poorly understood and some potential inconsistencies could arise when comparing $\mathrm{C}$ budget derived from terrestrial studies with those derived from aquatic studies. Here, we provide some additional evidence demonstrating that the transfer of terrestrial $\mathrm{C}$ to rivers could occur preferentially through land flooding. We suggest that wetlands behave not only as a significant source of atmospheric $\mathrm{CH}_{4}$ and a long-term $\mathrm{C}$ sink in soils (Mitsch et al., 2013) but also as an efficient $\mathrm{CO}_{2}$ pump that exports dissolved and particulate $\mathrm{C}$ to inland waters. This is particularly true for riparian and littoral wetlands that have strong connectivity with open inland waters. Using classical concepts in ecology, we analyse qualitatively and quantitatively how ecosystem production and respiration affect $\mathrm{C}$ export from drained land and from flooded land. We stress that our current understanding of processes and our ability to measure and quantify $\mathrm{C}$ metabolic and hydrological fluxes must be considerably improved to understand the origin of carbon in inland waters and predict future continental GHG budgets in the mosaic of continental ecosystems.

\section{Conceptualizing and formulating $\mathrm{C}$ fluxes}

Fluxes of $\mathrm{C}$ through the boundaries of an ecosystem - i.e. vertical exchange with the atmosphere and burial in soils and sediments on the one hand, and horizontal exchange between lands, wetlands and aquatic ecosystems on the other hand - are driven by metabolic processes in each ecosystem and physical processes that transport $\mathrm{C}$ such as hydrology, wind, turbulent mixing, and sediment deposition and resuspension. Following the conventions of Chapin III et al. (2006), the net $\mathrm{CO}_{2}$ exchange of an ecosystem with the atmosphere is partitioned into several forms of C fluxes (Fig. 2):

$-\mathrm{NEE}=\mathrm{NECB}+F_{\text {other }}+E$,

where NEE is net ecosystem exchange (the net $\mathrm{CO}_{2}$ flux from the ecosystem to the atmosphere); NECB is the net ecosystem carbon balance (the net $\mathrm{C}$ accumulation in the ecosystem); $F_{\text {other }}$ is the sum of vertical fluxes of volatile forms of $\mathrm{C}$ other than $\mathrm{CO}_{2}\left(\mathrm{CH}_{4}\right.$, carbon monoxide, volatile organic carbon) from the ecosystem to the atmosphere; and $E$ is horizontal C export by hydrological transport, trading of food, feed and wood (Ciais et al., 2008). Among the components of $E$, only hydrological horizontal transport of $\mathrm{C}$ will be discussed in this paper. All terms in Eq. (1) are net fluxes and can be positive of negative. Note that, by con- 
(a) Passive pipe

$2.6^{c}$

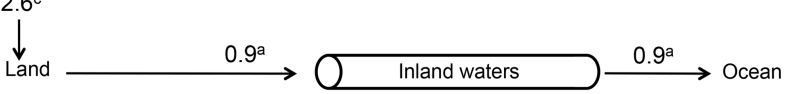

(b) Active pipe

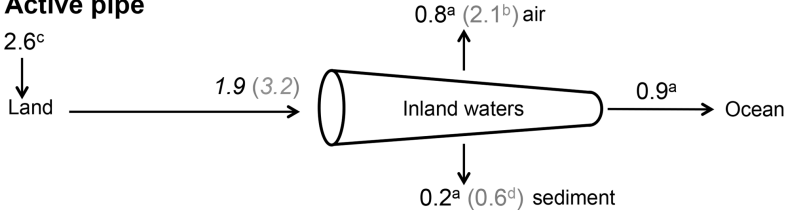

(c) Replumbed active pipe

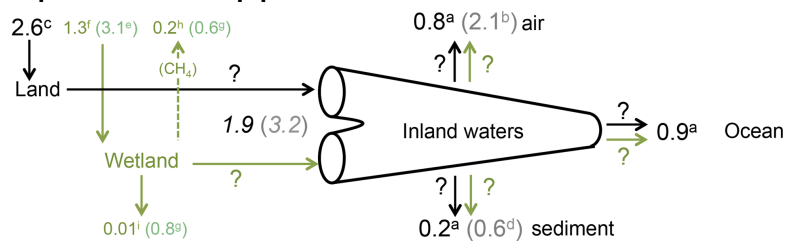

Figure 1. An update of the active pipe concept, including wetlands in the $\mathrm{C}$ budget of inland waters. ${ }^{\mathrm{a}}$ From Cole et al. (2007); ${ }^{\mathrm{b}}$ from Raymond et al. (2013) (note that the estimate of global $\mathrm{CO}_{2}$ outgassing from Cole et al., 2007, is similar to that of Lauerwald et al., 2015); ${ }^{\mathrm{c}}$ calculated as the difference between land use change and net land flux in Ciais et al. (2013); ${ }^{\mathrm{d}}$ from Tranvik et al. (2009); $\mathrm{e}^{\mathrm{e}}$ from Lu et al. (2016); ${ }^{\mathrm{f}}$ from Lu et al. (2016) corrected for a global wetland surface area of Downing et al. (2009); ${ }^{\mathrm{g}}$ from Mitsch et al. (2013); ${ }^{\mathrm{h}}$ from Saunois et al. (2016); ${ }^{\mathrm{i}}$ corrected from Mitsch et al. (2013), according to Bridgham et al. (2014). Numbers in italics are calculated as the sum of all others fluxes and include a high (grey) and a low (black) estimate. Black arrows represent $\mathrm{C}$ originating from well-drained, terrestrial ecosystems, and green arrows represent wetland $\mathrm{C}$.

vention, NEE is opposite in sign to NECB because NEE is defined by atmospheric scientists as a $\mathrm{C}$ input to the atmosphere, whereas NECB is defined by ecologists as a $\mathrm{C}$ input to ecosystems (Chapin III et al., 2006).

Regarding metabolic fluxes, net ecosystem production (NEP) is defined as

$\mathrm{NEP}=\mathrm{GPP}-\mathrm{ER}$,

where GPP is gross primary production and ER is ecosystem respiration. For conceptual and methodological reasons, it is necessary to consider separately the autotrophic and heterotrophic components of ER as

$\mathrm{NEP}=\mathrm{GPP}-\mathrm{AR}-\mathrm{HR}$,

$\mathrm{NPP}=\mathrm{GPP}-\mathrm{AR}$,

and

$\mathrm{NEP}=\mathrm{NPP}-\mathrm{HR}$,

where AR and HR are, respectively, the autotrophic and the heterotrophic components of ER and NPP is net primary production. A positive NEP (Eq. 2) reduces the concentration of $\mathrm{CO}_{2}$ and/or dissolved inorganic carbon (DIC) inside the ecosystem and generates a gradient that causes atmospheric $\mathrm{CO}_{2}$ to enter the ecosystem. One process that makes -NEE diverge from NEP and NECB is the entrance in or departure from the ecosystem of significant amounts of inorganic $\mathrm{C}$ as DIC in the aquatic phase with horizontal hydrological transport rather than through atmospheric exchange (Chapin III et al., 2006). However, DIC originating from dissolution of carbonate rock will not contribute to the difference between NEP and NECB. In addition to this divergence between NEE and NEP, NECB deviates from NEP when C enters or leaves the ecosystem in forms others than $\mathrm{CO}_{2}$ or DIC (Eq. 1). This includes horizontal transport of particulate and dissolved OC (POC and DOC) by hydrological processes, as well as vertical $\mathrm{CH}_{4}$ fluxes, and a secondary $\mathrm{C}$ flux that is significant for the active pipe concept, as well as for climate regulation.

As a first step, an adequate conceptualization of atmospheric $\mathrm{C}$ fluxes along watersheds implies the definition of functional entities inside the boundless $\mathrm{C}$ cycle (Battin et al. 2009), at least between three types of ecosystems that have fundamentally different properties with respect to atmospheric $\mathrm{CO}_{2}$ (Fig. 2): (1) the terrestrial, never-flooded land and its biosphere (forest, crops, shrub, grassland, and their well-drained soils and groundwater); (2) the floodable land and its mosaics of emergent wetlands with extremely variable ecological and hydrological properties; (3) the open waters of streams, lakes and rivers. Some estimations of $\mathrm{CO}_{2}$ outgassing from inland waters have included wetland surface areas generally estimated as the time-averaged flooded area (Richey et al., 2002; Aufdenkampe et al., 2011; Sawakuchi et al., 2017), while some others have not (Cole et al., 2007; Tranvik et al., 2009; Raymond et al., 2013). However, wetlands are functionally different from inland waters because their canopy of vegetation can alter the direction of atmospheric $\mathrm{CO}_{2}$ exchange (Raymond et al., 2013; Abril et al., 2014). Assuming that the $\mathrm{CO}_{2}$ flux at the water-air interface equals -NEE in wetlands (Richey et al., 2002) implicitly supposes that GPP and the aerial compartment of AR (Fig. 2b) are null or exactly balanced, which is incorrect. With respect to $\mathrm{C}$ cycling, the flooded land with emerged or floating vegetation has different properties from the drained land which is never flooded and whose topsoil is never waterlogged, as well as from the permanent and open waters of lakes. A definition based on flooding criteria has the advantage of allowing the clear delineation of the three subsystems using remote sensing (e.g. Melack and Hess, 2010) and is also functional with respect to the conceptualization and quantification of $\mathrm{C}$ cycling (Fig. 2). However, many wetland ecosystems are only seasonally flooded and experience emerged phases with ecological properties more similar to drained land; thus, $\mathrm{C}$ export by land flooding must be conceptualized as a transport mechanism that occurs during defined periods of time, even if it can mobilize highly significant amounts of $\mathrm{C}$ for the annual wetland budget. The surface areas of rivers, lakes and wetlands on the continents are still 


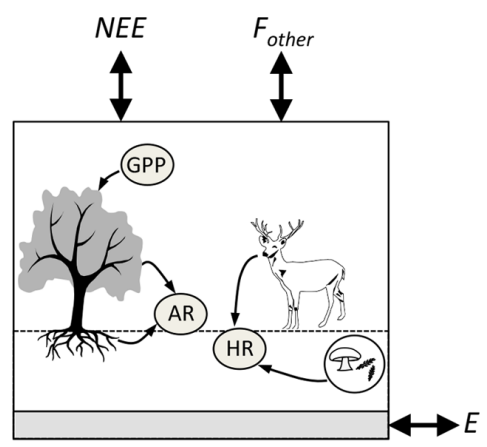

(a) Drained land

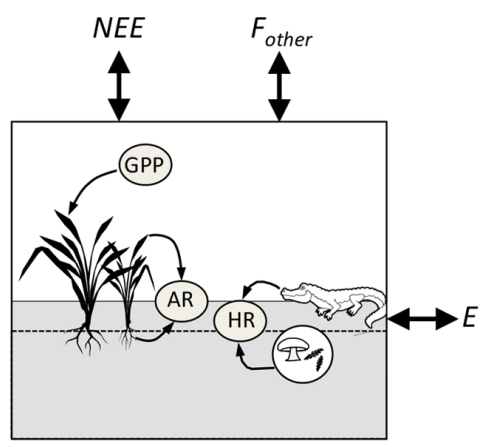

(b) Flooded land

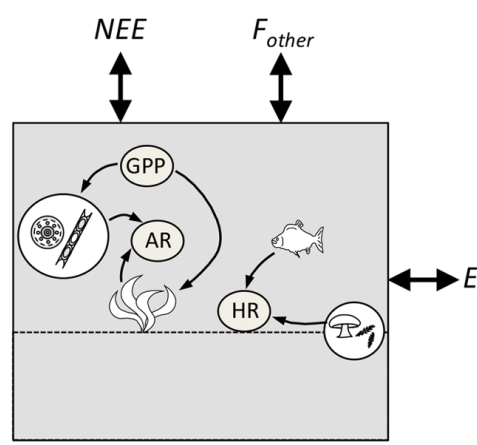

(c) Inland waters

Figure 2. Relationship among the carbon (C) fluxes (in italics) that determine net ecosystem carbon balance (NECB) (the net of all C imports to and exports from the ecosystem), as well as the metabolic fluxes (inside grey oval) that determine net ecosystem production (NEP). (Adapted from Chapin III et al., 2006, to include aquatic compartments.) The boxes represent the ecosystems: (a) drained land, (b) flooded land and (c) inland waters. Fluxes contributing to NECB are net ecosystem exchange (NEE) with the atmosphere (emissions to or uptake from the atmosphere of carbon dioxide, $\left.\mathrm{CO}_{2}\right)$; fluxes of carbon forms other than $\mathrm{CO}_{2}\left(F_{\text {other }}\right)$, which include methane $\left(\mathrm{CH}_{4}\right)$, carbon monoxide $(\mathrm{CO})$ and volatile organic $\mathrm{C}(\mathrm{VOC})$; lateral export $(E)$ or import of dissolved organic and inorganic $\mathrm{C}$ and particulate organic $\mathrm{C}$ by hydrological transport and other processes such as animal movement, wind deposition and erosion, and anthropogenic transport or harvest. In this study, we consider $F_{\text {other }}$ as the flux of $\mathrm{CH}_{4}$ from the ecosystem to the atmosphere and $E$ as hydrological export from the ecosystem as POC, DOC, dissolved $\mathrm{CO}_{2}$ and dissolved $\mathrm{CH}_{4}$. Fluxes contributing to NEP are gross primary production (GPP) and ecosystem respiration (ER). ER includes autotrophic respiration (AR) by the different components of vegetation (leaves, wood, roots and photosynthetic microbes) and heterotrophic respiration (HR) by prokaryotes, fungi and animals. The shaded volume in each box indicates the part of the ecosystem occupied by water. GPP and ER occur mostly above the water table in well-drained ecosystems, partly above and below the water table in flooded ecosystems, and exclusively in water and sediments in aquatic ecosystems.

subject to large uncertainties (Lehner and Döll, 2004; Downing, 2009; Allen and Pavelsky, 2018). In addition, the relative importance of each entity varies considerably with latitude and climate: about one half of lake areas are located in temperate regions and one half of global wetlands are found in the tropics (Table 1).

As a second step, our conceptual model should be twodimensional (vertical and up- and downriver) and should consider the hydrological net export term $E$ in Eq. (1) as a potentially significant component of -NEE and NECB (Fig. 2), in accordance with the active pipe concept. In welldrained terrestrial ecosystems, surface runoff and drainage export $\mathrm{C}$ to inland water, and $E$ is necessarily always positive. In inland waters and wetlands, $E$ must be conceptualized and quantified as the net balance between hydrological import to and export from the ecosystems and, depending on each case, $E$ can be positive or negative. In fact, $\mathrm{C}$ fluxes along watersheds must be seen as a cascade from one subsystem upstream to another subsystem downstream, as described by the river continuum concept (Vannote et al., 1980). Several chemical forms of $C$ are involved in the $E$ term, which can be written as the sum of the export of four terms:

$E=E_{\mathrm{POC}}+E_{\mathrm{DOC}}+E_{\mathrm{CO}_{2}}+E_{\mathrm{CH}_{4}}$.

Particulate and dissolved organic C (POC and DOC) are derived from NPP; DIC is in part the result of ER that releases dissolved $\mathrm{CO}_{2}$ (as well as $\mathrm{CH}_{4}$ ) to waters and in part the re- sult of chemical weathering that generates alkalinity. Weathering of carbonate and silicate rocks is mediated by soil $\mathrm{CO}_{2}$ derived from respiration, so that weathering is also a component of ER; however, the weathering of carbonate rock involves an additional mineral source of DIC which contributes to half of the alkalinity produced. Because chemical weathering is assumed to occur mostly upland, alkalinity is considered a relatively conservative chemical form of river C, although some exceptions have been reported in floodplains of tropical rivers (Bouchez et al., 2012; Geeraert et al., 2017). Here, we will discuss only the fraction of DIC that occurs as excess $\mathrm{CO}_{2}$, that is, the DIC that is potentially lost after complete water-air equilibration (Abril et al., 2000). Concerning dissolved $\mathrm{CH}_{4}$, the role of wetlands was identified in the literature for sustaining $\mathrm{CH}_{4}$ emissions in adjacent rivers (Borges et al., 2015b) and lakes (Juutinen et al., 2003). However, owing to its low solubility, high loss rates through microbial oxidation, and the fact that emissions from wetlands occur mostly as ebullition or through plants (Chanton and Whiting, 1995), contributing to the $F_{\text {other }}$ term in Fig. 2 b, the contribution of $E_{\mathrm{CH}_{4}}$ to $E$ is small (few percent) in most ecosystems.

NEE is generally negative in forests (Luyssaert et al., 2010; Ciais et al., 2013) and wetlands (Morison et al., 2000; Saunders et al., 2007; Lu et al., 2016) but positive in lakes and rivers (Cole et al., 1994, 2007; Raymond et al., 2013) (Fig. 3). Compared to NEE, exchange of $\mathrm{CH}_{4}$ with the atmosphere $\left(F_{\text {other }}\right.$ in Eq. 1$)$ is significant in wetlands but not in forests (Ciais et al., 2013; Saunois et al., 2016) and proba- 
Table 1. Surface areas of land, rivers (from Allen and Pavelsky, 2018), lakes and wetlands (from Lehner and Döll, 2004). Boreal refers to latitudes higher than $66^{\circ} \mathrm{N}$, temperate to latitudes between 34 and $66^{\circ} \mathrm{N}$ and between 34 and $66^{\circ} \mathrm{S}$, and tropical and subtropical to latitudes between $34^{\circ} \mathrm{N}$ and $34^{\circ} \mathrm{S}$. Note that the estimate of Downing (2009) gives larger surface areas for lakes and wetlands.

\begin{tabular}{lrrrr}
\hline & Land (excluding Antarctica) & Rivers & Lakes & Wetlands \\
\hline Surface areas $\left(\mathrm{km}^{2}\right)$ & & & & \\
\hline Boreal & 10417452 & 138083 & 796382 & 758381 \\
Temperate & 49208693 & 205109 & 1218642 & 3677205 \\
Tropical and subtropical & 75464855 & 429808 & 413006 & 4731415 \\
Total & 135091000 & 773000 & 2428030 & 9167001 \\
\hline Contribution of ecosystems to global land area & & & & \\
\hline Boreal & $8 \%$ & $0.1 \%$ & $0.6 \%$ & $0.6 \%$ \\
Temperate & $36 \%$ & $0.2 \%$ & $0.9 \%$ & $2.7 \%$ \\
Tropical and subtropical & $56 \%$ & $0.3 \%$ & $0.3 \%$ & $3.5 \%$ \\
\hline Contribution of ecosystems to regional land area & & & & \\
\hline Boreal & $100 \%$ & $1.3 \%$ & $7.6 \%$ & $7.3 \%$ \\
Temperate & $100 \%$ & $0.4 \%$ & $2.5 \%$ & $7.5 \%$ \\
Tropical and subtropical & $100 \%$ & $0.6 \%$ & $0.5 \%$ & $6.3 \%$ \\
\hline Regional contribution to ecosystem global area & & & & \\
\hline Boreal & $8 \%$ & $18 \%$ & $33 \%$ & $8 \%$ \\
Temperate & $36 \%$ & $27 \%$ & $50 \%$ & $40 \%$ \\
Tropical and subtropical & $56 \%$ & $56 \%$ & $17 \%$ & $52 \%$ \\
\hline
\end{tabular}

bly not in inland waters. Indeed, budgets of $\mathrm{CH}_{4}$ emissions from inland waters strongly depend on whether wetland areas were included or not, and, in general, open waters of rivers and lakes emit $\mathrm{CH}_{4}$ at rates approximately 100 times lower than $\mathrm{CO}_{2}$ (Melack et al., 2004; Bastviken et al., 2011; Borges et al., 2015a). The occurrence of a horizontal transport of C by streams and rivers implies a positive $E$ term in terrestrial ecosystems, where -NEE should exceed NECB. $E$ is probably also large in riparian and littoral wetlands, where -NEE likely exceeds net storage in soils plus $\mathrm{CH}_{4}$ emissions (Eq. 1; Fig. 1c). In contrast, in rivers and lakes, NECB exceeds -NEE and $E$ is negative (Cole and Caraco, 2001; Battin et al., 2008) because these ecosystems receive in general more $\mathrm{C}$ from upstream than they export downstream. In addition, the fact that part of $E$ occurs as OC implies that NEP exceeds NECB in terrestrial systems and wetlands that export OC, whereas NECB will exceed NEP for instance in lakes or estuaries that receive and store large amounts of allochthonous OC in their sediments (Lovett et al., 2006; Cole et al., 2007; Tranvik et al., 2009). In general, C fluxes at the boundaries of ecosystems and metabolic fluxes inside the ecosystems suggest that the magnitude of the export term $E$ in Eq. (1) and Fig. 2 and the deviation of -NEE from NECB and from NEP will strongly depend on their hydrological connectivity, together with the allocation of GPP and ER above and below water.

\section{The inland water perspective}

Global estimates of $\mathrm{CO}_{2}$ emissions from inland waters (Cole et al., 1994; Raymond et al., 2013; Lauerwald et al., 2015) are derived from $\mathrm{CO}_{2}$ flux intensities computed from the water-air gradient of the partial pressure of $\mathrm{CO}_{2}\left(p \mathrm{CO}_{2}\right)$ and the gas transfer velocity at the water-air interface and scaled to the surface area of lakes and rivers. Each of the three terms suffers for uncertainties and generally poor data coverage. Cole et al. (1994) provided the first quantification of the $\mathrm{CO}_{2}$ emission to the atmosphere from lakes $\left(0.1 \mathrm{PgC} \mathrm{yr}^{-1}\right)$, which was later confirmed by an updated calculation by Sobek et al. (2005). Cole and Caraco (2001) estimated global $\mathrm{CO}_{2}$ degassing for rivers and streams, which has been recently re-evaluated by Raymond et al. (2013) and Lauerwald et al. (2015). The two latter studies are based on $p \mathrm{CO}_{2}$ computed from $\mathrm{pH}$ and alkalinity from the same database (GLORICH, Hartmann et al., 2014) but with different data-selection criteria and scaling approaches. Raymond et al. (2013) extrapolated discrete $p \mathrm{CO}_{2}$ values per COSCATS catchment aggregated units (Meybeck et al., 2006) and obtained a global $\mathrm{CO}_{2}$ emission to the atmosphere of $0.3 \mathrm{PgC} \mathrm{yr}^{-1}$ from lakes and $1.8 \mathrm{PgC} \mathrm{yr}^{-1}$ from rivers and streams. A potential problem in this estimation comes from the calculation of $p \mathrm{CO}_{2}$ from $\mathrm{pH}$ and alkalinity, which greatly overestimates $p \mathrm{CO}_{2}$ (up to several hundred percent) in many acidic organic-rich "black" waters such as those found in the tropics and the boreal zone (Abril et al., 
(a) Drained land

$$
\begin{gathered}
\text { NEE } \\
\text { (negative) }
\end{gathered}
$$

(b) Inland waters

GPP

IR
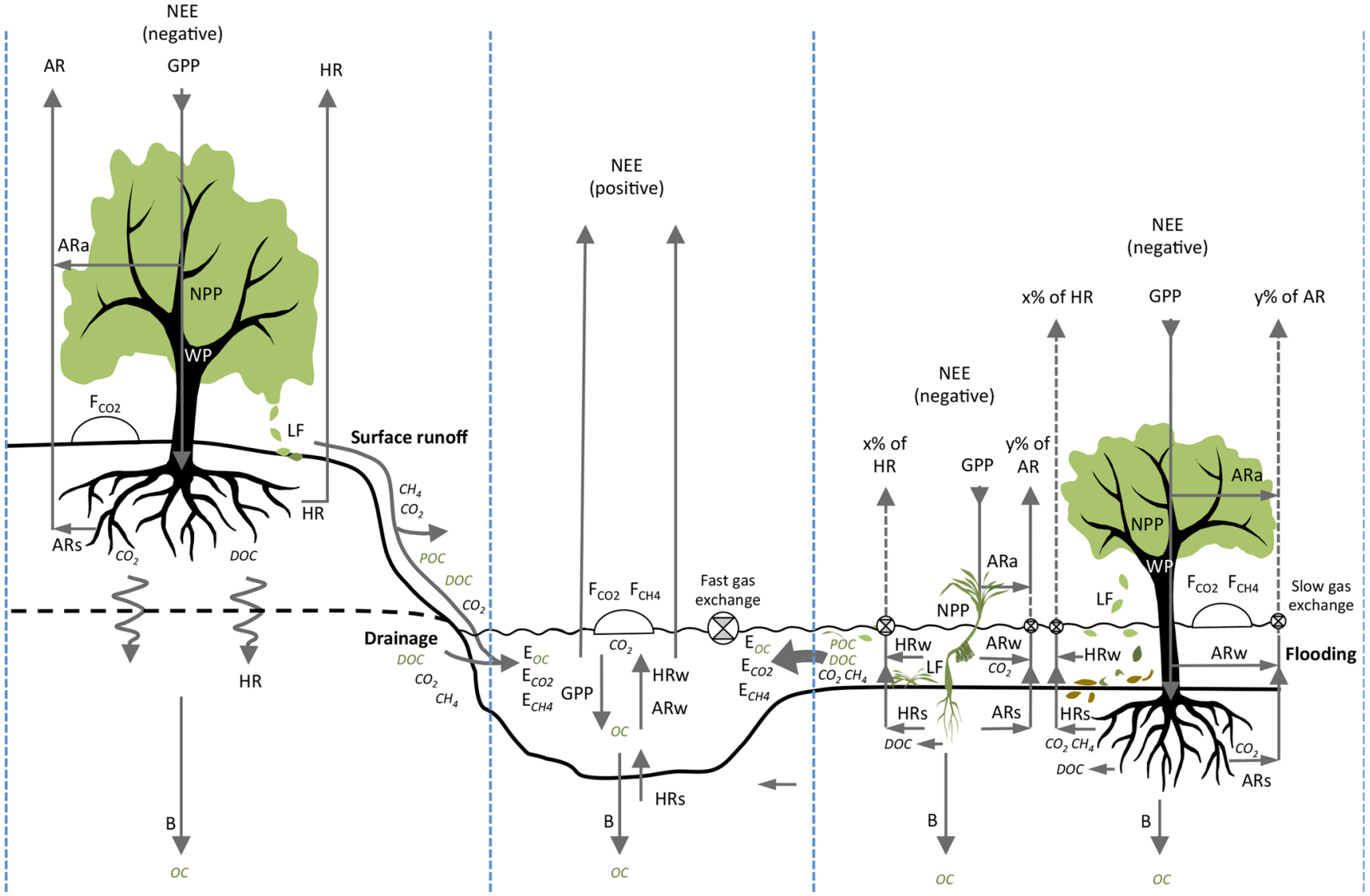

Figure 3. Functional differences of carbon metabolism and hydrological export in well-drained and flooded land. NEE: net ecosystem exchange; GPP: gross primary production; NPP: net primary production; WP: wood production; LF: litter fall; AR: autotrophic respiration; $\mathrm{AR}_{\mathrm{a}}$ : autotrophic respiration in air; $\mathrm{AR}_{\mathrm{W}}$ : autotrophic respiration in water; $\mathrm{AR}_{\mathrm{S}}$ : autotrophic respiration in soils and sediments; $\mathrm{HR}$ : heterotrophic respiration; $\mathrm{HR}_{\mathrm{W}}$ heterotrophic respiration in water; $\mathrm{HR}_{\mathrm{S}}$ heterotrophic respiration in sediments; $B$ : long-term burial in soils and sediments. POC: particulate organic C; DOC: dissolved organic C; $E_{\mathrm{OC}}$ : export of organic carbon (sum of DOC and POC); $E_{\mathrm{CO}_{2}}$ : export of dissolved $\mathrm{CO}_{2} ; E_{\mathrm{CH}_{4}}$ : export of dissolved $\mathrm{CH}_{4} ; \mathrm{F}_{\mathrm{CO}_{2}}$ and $F_{\mathrm{CH}_{4}}$ : fluxes of $\mathrm{CO}_{2}$ and $\mathrm{CH}_{4}$ at the soil-air or water-air interface (as determined with static chambers). Note that, by convention, NEE is opposite in sign to GPP and NPP because NEE is defined by atmospheric scientists as a $\mathrm{C}$ input to the atmosphere, whereas GPP and NPP are defined by ecologists as C inputs to ecosystems (Chapin III et al., 2006). C export to river systems results from the interactions between metabolic processes and $\mathrm{C}$ transport processes between air, plants, soils, sediments and waters, which are fairly different in flooded ecosystems (c) and terrestrial, well-drained ecosystems (a). In terrestrial drained systems, carbon export occurs as surface runoff and drainage and includes a small fraction of LF, root exudation, ARs, and HR. In contrast, in wetlands during flooding (c), almost all LF and root exudation (that releases DOC), as well as a substantial fraction of ecosystem respiration $\left(\mathrm{AR}_{\mathrm{W}}+\mathrm{AR}_{\mathrm{S}}+\mathrm{HR}_{\mathrm{W}}+\mathrm{HR}_{\mathrm{S}}\right)$, are transferring $\mathrm{C}$ to the aquatic system as $\mathrm{OC}$ and dissolved gases; in addition, slow gas exchange (low gas transfer velocity) in protected wetlands favours lateral export of dissolved $\mathrm{CO}_{2}$ and $\mathrm{CH}_{4}$. These lateral $\mathrm{C}$ fluxes are enhanced in flooded compared to drained systems and should generate strong discrepancies between ecosystem metabolic fluxes (GPP, NPP, ER and NECB) and vertical $\mathrm{C}$ fluxes measured in the field with static chambers $\left(\mathrm{F}_{\mathrm{CO}_{2}}\right.$ and $\left.F_{\mathrm{CH}_{4}}\right)$ and eddy-covariance towers (NEE).

2015). Lauerwald et al. (2015) computed river $p \mathrm{CO}_{2}$ values on a regular grid $\left(0.5^{\circ} \times 0.5^{\circ}\right)$, using a multiple regression model based on the GLORICH $p \mathrm{CO}_{2}$ data and modelled terrestrial NPP on the catchment, population density, air temperature and slope; this method provided a lower estimate of global $\mathrm{CO}_{2}$ emission for rivers of $0.7 \mathrm{PgC} \mathrm{yr}^{-1}$. The strong divergence of global $\mathrm{CO}_{2}$ emission estimates in these two studies most likely reflects the low data coverage in tropics that account for nearly $80 \%$ of the modelled global emission, although in the GLORICH database nearly all of the data in the tropics are from the Amazon. Recent direct $p \mathrm{CO}_{2}$ measurements in several African rivers (Borges et al., 2015a) and in the Amazon (Abril et al., 2014) scaled to the tropics with wetland coverage (Borges et al., 2015b) provide a value of $1.8 \pm 0.4 \mathrm{PgC} \mathrm{yr}^{-1}$ of $\mathrm{CO}_{2}$ outgassing from tropical rivers alone (latitude $<25^{\circ}$ ), thus in line with the higher es- 
timate of Raymond et al. (2013). The most recent estimates of river areal extent are higher than those used by Raymond et al. (2013) and Lauerwald et al. (2015) by $44 \%$ (Allen and Pavelsky, 2018), which should lead to an upward revision of $\mathrm{CO}_{2}$ fluvial emissions. A larger estimate of the global river $\mathrm{CO}_{2}$ outgassing of $3.9 \mathrm{PgC} \mathrm{yr}^{-1}$ has been published recently (Sawakuchi et al., 2017). However, we choose not to consider this number in our analysis because it is based on observations in the Amazon River that include the floodplain areas that belong to the wetland domain, with a canopy of emergent vegetation.

According to the active pipe concept (Fig. 1b), the emission of $\mathrm{CO}_{2}$ to the atmosphere from inland waters is attributed to terrestrial $\mathrm{C}$ fixed by plants on the catchment. The transfer occurs as (1) an input of dissolved $\mathrm{CO}_{2}$ (and $\mathrm{CH}_{4}$ ) originating from soil respiration, which will be further degassed from waters ( $E_{\mathrm{CO}_{2}}$ and $E_{\mathrm{CH}_{4}}$ in Eq. 6); and (2) an input of particulate and dissolved organic $\mathrm{C}\left(E_{\mathrm{DOC}}\right.$ and $\left.E_{\mathrm{POC}}\right)$ followed by heterotrophic degradation to $\mathrm{CO}_{2}$ and $\mathrm{CH}_{4}$ in the aquatic system (Del Giorgio et al., 1999; Prairie et al., 2002; Cole et al., 2000; Battin et al., 2008; Hotchkiss et al., 2015). Inland waters, particularly lakes, also store significant quantities of OC mainly of terrestrial origin in their sediments (Cole et al., 2007; Tranvik et al., 2009). In aquatic systems, all the GPP and ER occur in water and sediments (Fig. 2c) and can be quantified with in vitro or in situ incubations. In addition, the $\mathrm{CO}_{2}$ outgassing flux measured with floating chambers in open waters give a direct estimate of -NEE (although this method may create artefacts at the water-air interface), and diurnal changes in water $p \mathrm{CO}_{2}$ (or oxygen concentration) can provide an estimate of GPP and ER. In inland waters, Eqs. (1) and (2) are generally combined to a simplified equation that allows us to account for the inorganic $\mathrm{C}$ balance:

$-\mathrm{NEE}=\mathrm{NEP}+E_{\mathrm{CO}_{2}}$,

with NEE positive, NEP negative (heterotrophic metabolism) and $E_{\mathrm{CO}_{2}}$ negative, as rivers and lakes receive more dissolved $\mathrm{CO}_{2}$ from upstream than they export downstream. Battin et al. (2008) made a global synthesis of aquatic metabolism rate measurements (NEP) and confirmed that stream, river and estuarine ecosystems are overall net heterotrophic and respire a total flux of about $0.3 \mathrm{PgC} \mathrm{yr}^{-1}$. The fact that net heterotrophy (negative NEP) is in general lower than $\mathrm{CO}_{2}$ outgassing in inland waters led Hotchkiss et al. (2015) to differentiate "internal $\mathrm{CO}_{2}$ " (from - NEP) from "external $\mathrm{CO}_{2}$ " coming from groundwater or riparian inputs of DIC (negative $\left.E_{\mathrm{CO}_{2}}\right)$. Indeed, inputs of groundwater DIC are acknowledged as sustaining a significant fraction of the $\mathrm{CO}_{2}$ emissions from lakes (Butman and Raymond, 2011; McDonald et al., 2013) and from rivers, especially headwaters (Johnson et al., 2008; Hotchkiss et al., 2015; Deirmendjian and Abril, 2018). Horizontal transfer of respiration-derived DIC from forest or wetland soils to aquatic ecosystems explains why aquatic $\mathrm{NEE}\left(\mathrm{CO}_{2}\right.$ outgassing) greatly exceeds - NEP (negative NEP, net heterotrophic ecosystems) in rivers (Abril et al., 2014; Hotchkiss et al., 2015; Borges et al., 2015a). Conversely, this outgassing flux from aquatic systems implies that, in terrestrial ecosystems and wetlands that release DIC laterally, NEP exceeds -NEE. Finally, large exports of DOC and POC from ecosystems such as peatland occur preferentially at high water table (Freeman et al., 2001; Clark et al., 2008); the large DOC hydrological mobilization from swamps and bogs will make their - NEE much higher than their NECB (Eq. 1).

\section{The terrestrial perspective}

Hydrological $\mathrm{C}$ export as a significant loss term for terrestrial ecosystems has been considered in more detail only relatively recently (e.g. Ciais et al., 2008) and is included in only a very limited number of global terrestrial models (Tian et al., 2015; Lauerwald et al., 2017; Nakhavali et al., 2018). Terrestrial $\mathrm{C}$ budgets at the plot and the continental scales are based on different methods not consistent and precise enough to estimate hydrological $\mathrm{C}$ export as a residual flux. In addition, no direct standardized experimental method is available yet to directly estimate the flux of $\mathrm{C}$ across the boundary between land and water, and the $E$ term in Eq. (1) for terrestrial systems is almost always calculated from a $\mathrm{C}$ mass balance in inland waters (Fig. 1b; Ciais et al., 2013). Terrestrial -NEE calculated as the difference between land use change and net land $\mathrm{C}$ flux is estimated at $2.6 \mathrm{PgC} \mathrm{yr}^{-1}$ for the $2000 \mathrm{~s}$ (Ciais et al., 2013). In a conceptual model that ignores the different functionalities between floodable and drained land (Fig. 1b), depending on what estimates are used for the outgassing term (Raymond et al., 2013; Lauerwald et al., 2015) and for the sediment burial term (Cole et al., 2007; Tranvik et al., 2009), the hydrological export necessary to balance the inland water $\mathrm{C}$ budget is $1.9-3.2 \mathrm{PgC}^{-1}$, which corresponds to $75 \%-125 \%$ of the present net atmosphereland $\mathrm{C}$ flux (Fig. 1b). The atmosphere-land net $\mathrm{C}$ flux of 2. $6 \mathrm{PgC} \mathrm{yr}^{-1}$ is derived from multiple approaches including atmospheric $\mathrm{CO}_{2}$ inversion, terrestrial ecosystem models and forest inventories (Ciais et al., 2013). The atmospheric $\mathrm{CO}_{2}$ inversion method integrates large continental areas that include inland waters. Thus, the global -NEE calculated from continental-scale inversion models accounts for $\mathrm{CO}_{2}$ outgassing from inland waters. Intriguingly, the results of inversion methods are relatively consistent with forest inventories and process-based models that do not necessarily account for hydrological export (Ciais et al., 2013). However, when a comparison is made at the plot scale with eddy-covariance data, model performance is generally poor (Schwalm et al., 2010), and for instance modelled GPP can be overestimated by more than $100 \%$ in tropical forests (Stöckli et al., 2008). If a $-\mathrm{NEE}$ from atmospheric inversion is assumed close to NECB from inventories and process-based models, then the $E$ term (Eq. 1) is expected to be small, within the error of 
flux estimates from the terrestrial perspective. If outgassing of $\mathrm{CO}_{2}$ from freshwater is already included in -NEE calculated by atmospheric inversion methods, and if this - NEE value (2.0-3.0 $\left.\mathrm{PgC} \mathrm{yr}^{-1}\right)$ is very close to that of NECB (1.8$\left.2.3 \mathrm{PgC} \mathrm{yr}^{-1}\right)$, then terrestrial ecosystems barely export the $0.6-1.0 \mathrm{PgC} \mathrm{yr}^{-1}$ of recalcitrant $\mathrm{OC}$ that is buried in inland waters $\left(0.2-0.6 \mathrm{PgC} \mathrm{yr}^{-1}\right)$ and exported to the ocean $\left(0.4 \mathrm{PgC} \mathrm{yr}^{-1}\right)$.

Spatially, global forest carbon accumulation occurs in boreal and temperate regions, whereas tropical forests were found to be nearly neutral, with net emissions from land use change being compensated for by sinks in preserved tropical forests (Pan et al., 2011). In contrast, Lauerwald et al. (2015) estimated that $78 \%$ of global $\mathrm{CO}_{2}$ outgassing by rivers occurred at a latitude lower than $25^{\circ}$. Such latitudinal uncoupling between $\mathrm{CO}_{2}$ uptake by forests and $\mathrm{CO}_{2}$ outgassing from rivers and lakes is intriguing and merits an explanation. Indeed, it would imply that different climatic and/or anthropogenic forces are driving these continental fluxes, in contradiction with the positive spatial correlation between river $p \mathrm{CO}_{2}$, air temperature and terrestrial NPP at the global scale (Lauerwald et al., 2015). It should not be forgotten, however, that these correlations could be indirect. Indeed, field $p \mathrm{CO}_{2}$ data in the Amazon and in African rivers including the Congo River reveal a strong positive influence of flooding and the presence of wetlands on water $p \mathrm{CO}_{2}$ (Abril et al., 2014; Borges et al., 2015a, b).

In terrestrial systems, few local studies at the plot scale compare -NEE or NECB measurements with $E$ derived from groundwater, spring and/or stream sampling. These studies lead to very different conclusions from those of global modelling studies. In remnant mature forests of Pará, Brazil, Davidson et al. (2010) estimated the export of dissolved $\mathrm{CO}_{2}$ from soil and groundwater to streams at a value of 2-3 orders of magnitude lower than the forest soil respiration and NPP. In temperate climate, Kindler et al. (2011) quantified $\mathrm{C}$ leaching by combining a soil-water model and dissolved $\mathrm{C}$ analysis in soil water; these authors reported significant $E$ flux in croplands (25\% of NECB) and grasslands $(22 \%)$ but not in forests (less than $3 \%$ ). In a temperate, forested and well-drained watershed, Deirmendjian et al. (2018) monitored dissolved $\mathrm{C}$ concentrations in groundwater and streams and estimated a total export $E$ of $2 \%$ of -NEE as measured by eddy covariance at the same site. These modest export rates from forests in this limited number of studies appear contradictory with the necessity of a large $E$ term from terrestrial ecosystems (1.9-3.2 $\mathrm{PgC} \mathrm{yr}^{-1}$ in Fig. 1b) to fuel inland waters at the global scale (Cole et al., 2007; Ciais et al., 2013).

From an ecological point of view, a modest hydrological C export from well-drained lands is also supported by the nature of their NEP components and more specifically by the allocation of GPP and ER between air and water (Figs. 2, 3). In terrestrial systems, GPP assimilates atmospheric $\mathrm{CO}_{2}$, and $\mathrm{AR}$ releases $\mathrm{CO}_{2}$ partly in air $\left(\mathrm{AR}_{\mathrm{a}}\right)$, as foliar respiration, woody tissue respiration and, partly in soil $\left(\mathrm{AR}_{\mathrm{S}}\right)$, as root respiration. HR occurs almost entirely in soils $\left(\mathrm{HR}_{\mathrm{s}}\right)$. In forests, below-ground respiration generally accounts for 30\%-80\% of ER, and above-ground respiration accounts for the remaining fraction of ER (Davidson et al., 2006). Below-ground respiration in soils $\left(\mathrm{AR}_{\mathrm{S}}\right.$ and $\left.\mathrm{HR}\right)$ produces $\mathrm{CO}_{2}$ mainly in superficial well-drained soils, where root density is highest, which are enriched in biodegradable organic matter by litter fall and root exudation (Ryan and Law, 2005). When the land is well drained, this $\mathrm{CO}_{2}$ is released in the unsaturated zone of the soil and mostly returns to the atmosphere across the soil-air interface. In a tallgrass prairie, downward transfer of soil $\mathrm{CO}_{2}$ to groundwater was only approximately $1 \%$ of the soil-air $\mathrm{CO}_{2}$ efflux (Tsypin and Macpherson, 2012). For this reason, $\mathrm{CO}_{2}$ efflux from soils as measured with static chambers (Fig. 3) is commonly used as an integrative measure of soil respiration (Ryan and Law, 2005; Davidson et al., 2006) and, until now, by considering the loss of $\mathrm{CO}_{2}$ that dissolves in groundwater as negligible or within the error of estimation of metabolic flux at the ecosystem scale. In other terms, historical approaches in terrestrial ecosystems consisted in neglecting $F_{\text {other }}$ and $E$, combining Eqs. (1) and (2) to

$-\mathrm{NEE}=\mathrm{NECB}=\mathrm{NEP}=\mathrm{GPP}-\mathrm{ER}$.

The transfer of $\mathrm{C}$ from well-drained terrestrial ecosystems to aquatic systems (Fig. 3) occurs through mechanical erosion of superficial soil by runoff that mobilizes POC including young litter; more refractory mineral-bound $\mathrm{OC}$, as well as dissolved humic OC; and percolation of rainwater through soils that dissolves gaseous $\mathrm{CO}_{2}$ and soil $\mathrm{OC}$ and liberates DIC and DOC in groundwater, which is further drained to streams and rivers. The fraction of HR that occurs in groundwater is probably modest in well-drained ecosystems, as the deepest water-saturated soil horizons contain much less biodegradable organic matter than the superficial soil (Ryan and Law, 2005; Deirmendjian et al., 2018). A modest export rate from forests is thus consistent with the allocation of forest metabolism (in particular ER) mainly above the water table (Fig. 2a), and with only few percent of -NEE ultimately reaching the aquatic system in non-flooding conditions (Fig. 3).

\section{The wetland perspective}

Even though wetlands cover an area of only approximately $10 \%$ of land surface (Downing, 2009), they act as hotspots of productivity and $\mathrm{CH}_{4}$ emissions (Saunois et al., 2016). In addition, many wetlands, such as riparian and littoral wetlands, have strong hydrological connections with streams, rivers and lakes. Ecologists formulated the hypothesis of wetlands as efficient $\mathrm{C}$ exporters long ago. Mulholland and Kuenzler (1979) reported several-fold higher DOC export from swamps than from the surrounding landscape in North Carolina (US). Junk (1985) described floodplain wetlands 
as a source of POC for the Amazon River; Wetzel (1992) named littoral wetlands of lakes as "metabolic gates" for nutrients and organic $\mathrm{C}$ between terrestrial and aquatic ecosystems. More recently, using a landscape ecological approach, Jenerette and Lal (2005) commented on the determinant influence of hydrology on wetland C fluxes, including downstream export to open waters. Consequently, hydrological variation (the second dimension of the conceptual 2$\mathrm{D}$ model) was identified as a factor of large uncertainty in wetland C cycling (Jenerette and Lal, 2005). Indeed, current available quantitative information on the $\mathrm{C}$ export flux (Eq. 6) is particularly scarce. In wetlands, the quantification of metabolic $\mathrm{C}$ fluxes and the understanding of biogeochemical processes regulating -NEE, NEP, ER, and NECB have a high degree of uncertainty. (i) The partitioning of wetland community metabolism between air, water and sediment and (ii) the complex biological and physical processes that transfer $\mathrm{C}$ in gaseous, dissolved, and particulate forms between these three sub-compartments are only partially understood (e.g. Hamilton et al., 1995); they are also highly variable in time and space and difficult to measure in practice. Connectivity between wetlands and inland waters strongly impacts the magnitude of the $E$ term in Eq. (1) and is much stronger in riparian and littoral wetlands than in swamps or bogs. Large variations in $E$ are also expected with climate and latitude, due to differences in seasonal land flooding and the relative surface areas of rivers, lakes and wetlands in boreal, temperate and tropical regions (Table 1).

The few estimates of wetland $\mathrm{C}$ fluxes at the global scale strongly vary depending first on the surface area considered for upscaling (Fig. 1c). Lehner and Döll (2004) calculated a wetland surface area of $9-11 \times 10^{6} \mathrm{~km}^{2}$, Mitsch et al. (2013) have used a value of $7 \times 10^{6} \mathrm{~km}^{2}$ and Downing (2009) reevaluated the total wetland area including smaller systems to $13-16 \times 10^{6} \mathrm{~km}^{2}$. Based on remote sensing data, Papa et al. (2010) provide a mean total surface area of $3.4 \times 10^{6} \mathrm{~km}^{2}$, with $56 \%$ located in the tropics, in agreement with previous estimates by Prigent et al. (2001, 2007). More recently, Lu et al. (2016) use a larger but probably unrealistic value of $33 \times 10^{6} \mathrm{~km}^{2}$. Global wetland $\mathrm{C}$ fluxes consist in three major terms in Eq. (1): (1) - NEE obtained from eddy-covariance measurements was upscaled to a value of 3.2 $\mathrm{PgC} \mathrm{yr}^{-1}$ (Lu et al., 2016), an estimate that needs to be corrected to $1.3 \mathrm{PgC} \mathrm{yr}^{-1}$ when applying the surface area re-evaluated by Downing (2009); in addition, the arithmetic mean of available eddy-covariance data (Lu et al., 2016) is probably not the most appropriate way to upscale - NEE at the global scale, and a more precise typology of wetland $-\mathrm{NEE}$ is necessary, based for instance on the classification of Lehner and Döll (2004). (2) NECB is assumed to be equal to organic $\mathrm{C}$ sequestration in soils and estimated from ${ }^{210} \mathrm{~Pb}$ and ${ }^{137}$ Cs core dating (Mitsch et al., 2013), a method that ignores slow decay in the soil $\mathrm{C}$ pool and can result in unrealistically high soil C sequestration rates (Bridgham et al., 2014); indeed, Mitsch et al. (2013) proposed a global C sequestration value of $0.8 \mathrm{PgC} \mathrm{yr}^{-1}$, whereas Bridgham et al. (2014) reevaluated this value to less than $0.01 \mathrm{PgC} \mathrm{yr}^{-1}$. (3) The $F_{\text {other }}$ term for wetlands is mainly composed of $\mathrm{CH}_{4}$ emissions and estimated from bottom-up approaches using static chambers and process-based models (Mitsch et al., 2013; Saunois et al., 2016), as well as top-down inversion models based on atmospheric data (Saunois et al., 2016). Recent published estimates for the global wetland $\mathrm{CH}_{4}$ flux range between $0.2 \mathrm{PgC} \mathrm{yr}^{-1}$ (Saunois et al., 2016) and 0.6 $\mathrm{PgC} \mathrm{yr}^{-1}$ (Mitsch et al., 2013). Wetland $C$ sources and sinks are thus subject to large uncertainties but still support the possibility of a residual C flux able to contribute significantly to river and lake $\mathrm{C}$ budgets at the global scale (Fig. 1c).

Eddy covariance reveals strong negative $\mathrm{NEE}\left(\mathrm{CO}_{2}\right.$ sink) in most wetlands (Morison et al., 2000; Jones and Humphries, 2002; Saunders et al., 2007; Lu et al., 2016). However, if wetland $E$ as DIC is ignored but significant, GPP and NPP deduced from the diurnal changes of eddy $\mathrm{CO}_{2}$ fluxes (Lu et al., 2016) would be overestimated and, inversely, ER would be underestimated (Eqs. 1-6). This point is particularly crucial because in flooded land the emerged compartment contains most of the photosynthetic parts of the ecosystem (GPP, NPP) fixing $\mathrm{CO}_{2}$ directly from the atmosphere, whereas the submerged compartment contains most of the respiratory parts of the ecosystem (ER, HR and a large fraction of AR) releasing $\mathrm{CO}_{2}$ to waters but only part of it back to the atmosphere because of gas-exchange limitation at the water-air interface (Fig. 3). Wetland 1-D mass-balance budgets also include an estimation of NPP, based on biomass inventories (Mitsch et al., 2013; Sjögersten et al., 2014). One problem with NPP data is that they do not account for all the $\mathrm{C}$ transferred by the plants from the atmosphere to the soil and water; indeed, as the sum of NEP and HR (Eq. 5), NPP does not include the fraction of GPP that is recycled by $\mathrm{AR}$ and, most importantly, the root respiration in sediment and water, which is highly significant below floating plant meadows (Bedford et al., 1991; Hamilton et al., 1995) and in flooded forest (Piedade et al., 2010). Total AR in flooded ecosystems should be divided into three components according to

$\mathrm{AR}=\mathrm{AR}_{\mathrm{a}}+\mathrm{AR}_{\mathrm{w}}+\mathrm{AR}_{\mathrm{s}}$,

where $\mathrm{AR}_{\mathrm{a}}, \mathrm{AR}_{\mathrm{w}}$ and $\mathrm{AR}_{\mathrm{S}}$ are the fraction of $\mathrm{AR}$ occurring in air, water and soils, respectively (Fig. 3). In flooded land, a canopy of vegetation generally protects the water-air interface from wind stress and the gas transfer velocity is lower compared to surrounding open waters (Foster-Martinez and Variano, 2016; Ho et al., 2018). Consequently, only a limited fraction of $\mathrm{AR}_{\mathrm{w}}$ and $\mathrm{AR}_{\mathrm{s}}$ will contribute to the $\mathrm{CO}_{2}$ fluxes measured with static chambers in wetlands. This is a second reason why wetland mass balances are incomplete and may artificially shift wetlands to atmospheric $\mathrm{C}$ sources or sinks (Sjögersten et al., 2014).

The allocation of $\mathrm{C}$ stocks and metabolism above and below water is fundamentally different in flooded land com- 
pared to well-drained land, and this considerably modifies their ecological functionalities (Figs. 2 and 3). Although some wetland plants also use DIC from water for photosynthesis, a large majority of wetland GPP is made by the emerged part of plants that fix atmospheric $\mathrm{CO}_{2}$ during the emersion periods and/or during the flooding thanks to their emerged or floating canopies (Piedade et al., 1994; Parolin et al., 2001; Engle et al., 2008). A large fraction (excluding wood) of the wetland biomass produced annually is transferred directly to water and sediment as litter fall and fine root production, where it fuels HR, including methanogenesis. Beside some important $\mathrm{CH}_{4}$ oxidation (Segarra et al., 2015), this leads to a $F_{\text {other }}$ (Eq. 1) as $\mathrm{CH}_{4}$ fluxes more significantly in wetlands than in well-drained terrestrial ecosystems (Ciais et al., 2013; Saunois et al., 2016). In addition, because of anaerobic conditions in their soils, watertolerant plants can develop morphological aeration strategies (Haase and Rätsch, 2010) that actively transport oxygen to the root zone and enhance respiration and the release of dissolved $\mathrm{CO}_{2}, \mathrm{CH}_{4}$ and other fermentative organic compounds such as ethanol to waters and pore waters (Bedford et al., 1991; Hamilton et al., 1995; Piedade et al., 2010). Plants also transport $\mathrm{CH}_{4}$ directly from sediments to the atmosphere (Byrnes et al., 1995). Wetland water below plant canopies is generally hypoxic and highly supersaturated in $\mathrm{CO}_{2}$ (Bedford et al., 1991; Abril et al., 2014) and $\mathrm{CH}_{4}$ (Hamilton et al., 1995; Borges et al., 2015b). Because the water-air interface behaves as a strong physical barrier for gas diffusion, depending on hydrological features, dissolved $\mathrm{CO}_{2}$ from swamps, marshes and floodplains' waters can be transported downriver for a long distance before being emitted to the atmosphere (Abril et al., 2014; Borges et al., 2015b). Lateral export of $\mathrm{C}$ from wetland to inland waters can follow different patterns depending on the hydrological connectivity and the frequency of flooding. Some almost permanently flooded wetlands will contribute continuously, whereas wetlands episodically flooded will contribute only during short periods through this mechanism. Nevertheless, $\mathrm{C}$ lateral fluxes induced by flooding during these short periods can still be very significant in the annual $\mathrm{C}$ budget of wetlands and rivers.

All these observations suggest the occurrence of a wetland $\mathrm{CO}_{2}$ pump that captures atmospheric $\mathrm{CO}_{2}$ and exports organic and inorganic $\mathrm{C}$ to rivers and lakes. This biological pump is also consistent with chamber measurements that generally identify $\mathrm{CO}_{2}$ sinks in vegetated flooded areas and $\mathrm{CO}_{2}$ sources in adjacent open waters (Pierobon et al., 2010; Ribaudo et al., 2012; Peixoto et al., 2016). It is worth noting that little is known on how wetland -NEE is affected by hydrology. For instance, a swamp of papyrus (Cyperus papyrus) on a sheltered shore of Lake Naivasha, Kenya, was a $\mathrm{CO}_{2}$ sink during immersion but a $\mathrm{CO}_{2}$ source during emersion, when large amounts of plant detritus accumulated in soils were exposed to air (Jones and Humphries, 2002). In contrast, in the more hydrologically dynamic Amazon flood- plain, Brazil, a stand of Echinochloa polystachya, another $\mathrm{C}_{4}$ plant, was a $\mathrm{CO}_{2}$ sink during both immersion and emersion (Morison et al., 2000). This suggests that a more efficient hydrological export of $\mathrm{C}$ in Amazon floodplains compared to Lake Naivasha could have promoted an annual negative NEE (Eq. 1). Such competition between $\mathrm{C}$ export and burial is also consistent with the more efficient $\mathrm{C}$ burial (B term in Fig. 3) in low flow-through wetlands (Mitsch et al., 2013).

Concerning the metabolic $\mathrm{C}$ balance of wetlands during flooding, the fraction of OC produced by NPP that is not respired in situ or buried in the wetland soil is exported to rivers systems as OC (Fig. 3), according to

$\mathrm{NPP}=B+\mathrm{HR}+E_{\mathrm{POC}}+E_{\mathrm{DOC}}$,

$\mathrm{NEP}=B+E_{\mathrm{POC}}+E_{\mathrm{DOC}}$,

where $B$ is the OC burial in the wetland soil. Thus, the export of POC and DOC from wetlands is expressed as

$E_{\mathrm{POC}}+E_{\mathrm{DOC}}=\mathrm{NEP}-B=\mathrm{NPP}-\mathrm{HR}-B$.

Downstream, this organic material will undergo intense degradation in inland water (negative NEP), contributing to $\mathrm{CO}_{2}$ outgassing through the OC detrital pathway (Cole and Caraco, 2001; Battin et al., 2008).

Plants and microbes respiring in water, sediments and the root zone $\left(\mathrm{AR}_{\mathrm{W}}, \mathrm{AR}_{\mathrm{S}}\right.$ and $\left.\mathrm{HR}\right)$ release dissolved $\mathrm{CO}_{2}$ in wetland water. During flooding, $\mathrm{AR}_{\mathrm{a}}$ is the only component of ER not contributing to $E_{\mathrm{CO}_{2}}$. The fraction $\alpha$ of wetland ER occurring in water and sediment $\left(\mathrm{AR}_{\mathrm{w}}\right.$ and $\left.\mathrm{AR}_{\mathrm{s}}\right)$ and almost all of the microbial $\mathrm{HR}$ (Eq. 11) release dissolved $\mathrm{CO}_{2}$ (and $\mathrm{CH}_{4}$ ) to waters:

$\alpha \mathrm{ER}=\mathrm{AR}_{\mathrm{w}}+\mathrm{AR}_{\mathrm{s}}+\mathrm{HR}$ with $(0<\alpha<1)$.

Part of these dissolved gases is emitted to the atmosphere, and another part is exported by the water flow:

$\alpha \mathrm{ER}=F_{\mathrm{CO}_{2}}+F_{\mathrm{CH}_{4}}+E_{\mathrm{CO}_{2}}+E_{\mathrm{CH}_{4}}$,

with

$$
\begin{gathered}
E_{\mathrm{CO}_{2}}=\alpha \beta \mathrm{ER} \text { and } F_{\mathrm{CO}_{2}}=\alpha(1-\beta) \mathrm{ER} \\
\text { and }(0<\beta<1) .
\end{gathered}
$$

$\alpha \beta$ is thus the fraction of ecosystem respiration that is exported laterally from the wetland in water masses. For simplification, we do not include $E_{\mathrm{CH}_{4}}$ in Eq. (13) because this term is assumed to be modest (few \%) compared to $E_{\mathrm{CO}_{2}}$. Indeed, the $\beta$ term might be much smaller for $\mathrm{CH}_{4}$ than for $\mathrm{CO}_{2}$ due to preferential $\mathrm{CH}_{4}$ ebullition and transport through plants in wetlands (Chanton and Whiting, 1995). For $\mathrm{CO}_{2}$, the fraction $\beta$ depends on hydrological and geomorphological parameters such as water depth, velocity and gas exchange in the wetland. Using a simple model of lateral dissolved gas transport (Abril et al., 2014), typical values of $1 \mathrm{~cm} \mathrm{~h}^{-1}$ for the 
gas transfer velocity (Foster-Martinez and Variano, 2016; Ho et al., 2018) and 5000 ppmv for water $p \mathrm{CO}_{2}$, we calculated a $\beta$ value of 0.93 for a water column of $1 \mathrm{~m}$ depth flowing at a velocity of $10 \mathrm{~cm} \mathrm{~s}^{-1}$ in a $100 \mathrm{~m}$ long wetland (assumed conditions for riparian wetlands during maximum flood). When the water depth is set at $0.1 \mathrm{~m}$ instead of $1 \mathrm{~m}$ or the water velocity is established at $1 \mathrm{~cm} \mathrm{~s}^{-1}$ instead of $10 \mathrm{~cm} \mathrm{~s}^{-1}, \beta$ decreases to 0.53 . Consequently, a large majority of the $\mathrm{CO}_{2}$ produced by wetland below-water respiration is outgassed to the atmosphere outside of the wetland. Finally, accounting for all terms in Eq. (6) in wetlands leads to total export expressed as

$$
\begin{aligned}
E & =\left(E_{\mathrm{DOC}}+E_{\mathrm{POC}}\right)+\left(E_{\mathrm{CO}_{2}}+E_{\mathrm{CH}_{4}}\right) \\
& =(\mathrm{NPP}-\mathrm{HR}-B)+\left(\beta \alpha \mathrm{ER}-F_{\mathrm{CO}_{2}}-F_{\mathrm{CH}_{4}}\right), \\
E & =\left(E_{\mathrm{DOC}}+E_{\mathrm{POC}}\right)+\left(E_{\mathrm{CO}_{2}}+E_{\mathrm{CH}_{4}}\right) \\
& =(\mathrm{NPP}-\mathrm{HR}-B)+\left(\beta\left(\mathrm{AR}_{\mathrm{w}}+\mathrm{AR}_{\mathrm{s}}+\mathrm{HR}\right)\right. \\
& \left.-F_{\mathrm{CO}_{2}}-F_{\mathrm{CH}_{4}}\right), \\
E & =\mathrm{NPP}-B+\beta \mathrm{AR}_{\mathrm{w}}+\beta \mathrm{AR}_{\mathrm{s}}+(\beta-1) \mathrm{HR} \\
& -F_{\mathrm{CO}_{2}}-F_{\mathrm{CH}_{4}} .
\end{aligned}
$$

The correct 2-D wetland mass-balance budget in flooded ecosystems is also calculated as

$$
\begin{aligned}
& \mathrm{NPP}+\beta \mathrm{AR}_{\mathrm{w}}+\beta \mathrm{AR}_{\mathrm{s}}-(1-\beta) \mathrm{HR} \\
& \quad=B+F_{\mathrm{CO}_{2}}+F_{\mathrm{CH}_{4}}+E .
\end{aligned}
$$

The three terms $\mathrm{AR}_{\mathrm{w}}, \mathrm{AR}_{\mathrm{s}}$ and $\mathrm{HR}$ together with the $E$ term are generally neglected in wetland $\mathrm{C}$ budgets that quantify only NPP, $F_{\mathrm{CO}_{2}}, F_{\mathrm{CH}_{4}}$ and $B$ (Mitsch et al., 2013; Sjögersten et al., 2014).

\section{What tools do plumbers need?}

Quantifying hydrological C export from wetlands at the ecosystem, regional and global scales would require information that to date is still missing or incomplete. General recommendations include more systematic field observations of $\mathrm{C}$ fluxes across the boundaries of wetlands with the atmosphere, the upland and the river. Eddy-covariance data are still lacking in some remote wetlands where logistics are complicated (Lu et al., 2016), for example in floodplains of large tropical rivers, which host highly productive flooded forests and floating macrophytes (Piedade et al., 1994; Morison et al., 2000), and largely contribute to riverine global $\mathrm{CO}_{2}$ and $\mathrm{CH}_{4}$ emissions (Richey et al., 2002; Engle et al., 2008; Bloom et al., 2010; Abril et al., 2014; Borges et al., 2015a). Eddy-covariance measurements should also be more systematically coupled at the same site with chamber measurements, hydrological $\mathrm{C}$ fluxes and $\mathrm{C}$ sequestration studies but accounting for the longer timescale of the sequestration rates based on core dating.

The quantification in the field of the amount of $\mathrm{C}$ that enters or leaves wetland ecosystems horizontally with wa- ter flow is challenging because many wetlands have complex morphologies and multiple pathways of hydrological transport that can be apprehended only using hydrodynamical modelling. In addition to hydrological complexity, the $\mathrm{C}$ chemical forms may largely change when water crosses the wetland and, for instance, fine terrestrial mineral-bound POC can be trapped and replaced by wetland coarser POC, DOC and dissolved $\mathrm{CO}_{2}$. Isotopic and molecular tracers can help in differentiating terrestrial from wetland $\mathrm{OC}$, when the signatures of the two sources are well separated; for instance, in watersheds dominated by $\mathrm{C}_{3}$ forests, the contribution of wetland $\mathrm{C}_{4}$ macrophytes can be tracked with $\delta^{13} \mathrm{C}$ in riverine POC, DOC and DIC (Quay et al., 1992; Mortillaro et al., 2011; Albéric et al., 2018). In contrast, OC from flooded forests is more difficult to differentiate from that coming from terra firme forests (Ward et al., 2013) when many tree species are common to both ecosystems (Junk et al., 2010). Radiocarbon age in rivers can be interpreted as the time spent by $\mathrm{C}$ in soils and, when young $\mathrm{C}$ predominates, radiocarbon data suggest a rapid transfer from plants to waters (Mayorga et al., 2005), as expected in highly productive riparian wetlands. However, some wetlands such as peats can also export old DOC to streams (Billet et al., 2007).

Original experimental work in mesocosms that simulate flooding and wetland ecosystem manipulations are necessary to characterize and quantify hydrological $\mathrm{C}$ export annually per flooded area, as well as the fraction of ecosystem respiration occurring below water; methods must be developed to estimate $\mathrm{HR}, \mathrm{AR}_{\mathrm{W}}$ and $\mathrm{AR}_{\mathrm{s}}$ during immersed and emerged periods (Eqs. 13-15). Soil core incubations or submerged static chambers, for instance, provide an estimate of $\mathrm{HR}_{\mathrm{s}}$ plus a fraction of $\mathrm{AR}_{\mathrm{s}}$ in some flooded areas with small plants that can be captured in the chamber; in the absence of phytoplankton, dark water incubations measure $\mathrm{HR}_{\mathrm{W}}$ but miss $\mathrm{AR}_{\mathrm{w}}$ by the submerged part of plants. Special mesocosms adapted to the metabolism of semiaquatic plants are thus necessary. Data of metabolic rates would allow building coupled hydrological-biogeochemical models of wetlands accounting for flooded and non-flooded periods. Process-based biogeochemical models are indeed promising approaches for quantifying $\mathrm{C}$ exports from flooded lands (e.g. Sharifi et al., 2013; Lauerwald et al., 2017). Ideally, these models could simulate the most important biological processes in the wetland: GPP; NPP; litter fall; and the different components of ER in air, water and soil, together with hydrological transport and gas emission. Few modelling studies account for DOC export (Sharifi et al., 2013) - most miss the DIC export as dissolved $\mathrm{CO}_{2}$ and do not correctly account for the autotrophic respiration terms $\left(\mathrm{AR}_{\mathrm{w}}\right.$ and $\left.\mathrm{AR}_{\mathrm{s}}\right)$ or the heterotrophic microbial processes in the root zone $\left(\mathrm{HR}_{\mathrm{s}}\right)$ (Fig. 2). Recently, Lauerwald et al. (2017) developed a new type of model of $\mathrm{C}$ cycling in large rivers that mimics the most important physical and biological processes, including an empirical equation during land flooding; when applied to the Amazon River, the model calculated a total $\mathrm{CO}_{2}$ out- 
gassing flux close to that upscaled from field measurements (Richey et al., 2002); in addition, the computed annual relative contributions to the total dissolved $\mathrm{C}$ inputs of surface runoff $(14 \%)$, drainage $(28 \%)$ and flooding $(57 \%)$ were consistent with recent field evidence that wetlands predominantly fuel $\mathrm{CO}_{2}$ outgassing from the Amazon River (Abril et al., 2014).

Finally, a precise upscaling of wetland and inland waters' global $\mathrm{C}$ budgets requires an adequate typology of $\mathrm{C}$ cycles that accounts for the different hydrological and biogeochemical functioning of peats, swamps, marshes and floodplains, and their spatial distributions along climatic zones (Lehner and Döll, 2004). While large-scale wetlands such as tropical flooded forests can be determined by remote sensing and are available in spatial data sets such as the Global Land Cover 2009 (Bontemps et al., 2011), there are no global data sets for smaller-scale and elusive structures such as meadows of macrophytes that are important components of floodplains and riparian wetlands. However, progress has been made to develop algorithms to treat fine-resolution remote sensing data for local applications (Villa et al., 2018). Ideally, these global geo-referenced databases could also include metabolic parameters such as ecosystem productivity, respiration and $\mathrm{CH}_{4}$ emission, as well as simplified parameters that describe hydrological connectivity and exposure time to flooding (e.g. Oldham et al., 2013). Process-based models could also be built and validated in individual wetland types, and then aggregated to a global model able to quantify $\mathrm{C}$ fluxes between drained land, floodable land, rivers and lakes, and the atmosphere at the continental scale. Such modelling tools will also be highly valuable to predict the impacts of climate and land use changes on these continental $\mathrm{C}$ fluxes. Knowing the relative contribution of well-drained and flooded land to inland water $\mathrm{CO}_{2}$ emissions is crucial for quantifying the continental greenhouse gas budget (Fig. 1) and predicting its sensitivity and feedback on climate warming. For instance, the intensification of floods and droughts or river damming has the potential to drastically modify $\mathrm{C}$ fluxes at the land-water-atmosphere interface and alter or enhance the hotspot character of wetlands in the continental C cycle. Such evolution must be monitored in the field, better understood, conceptualized and modelled in order to guide environmental conservation strategies in the next decades.

Data availability. No data sets were used in this article.

Author contributions. GA designed the study, conceived Figs. 2 and 3, and wrote the set of equations; AVB conceived Fig. 1 and Table 1; GA and AVB equally contributed to literature reading and the writing of the paper.
Competing interests. The authors declare that they have no conflict of interest.

Acknowledgements. This contributes to the European Research Council Starting Grant AFRIVAL (240002), the French National Research Agency CARBAMA project (grant no. 08-BLANC-0221) and the CNP-Leyre project funded by the Cluster of Excellence COTE at the Université de Bordeaux (ANR-10-LABX-45). Alberto $\mathrm{V}$. Borges is a senior research associate at the Fonds National de la Recherche Scientifique.

Edited by: Tom J. Battin

Reviewed by: two anonymous referees

\section{References}

Abril, G., Etcheber, H., Borges, A. V., and Frankignoulle, M.: Excess atmospheric carbon dioxide transported by rivers into the Scheldt Estuary, CR Acad. Sci. II A, 330, 761-768, 2000.

Abril, G., Martinez, J.-M., Artigas, L. F., Moreira-Turcq, P., Benedetti, M. F., Vidal L., Meziane, T., Kim, J.-H., Bernardes, M. C., Savoye, N., Deborde, J., Albéric, P., Souza, M. F. L., Souza, E. L., and Roland, F.: Amazon River Carbon Dioxide Outgassing fuelled by Wetlands, Nature, 505, 395-398, 2014.

Abril, G., Bouillon, S., Darchambeau, F., Teodoru, C. R., Marwick, T. R., Tamooh, F., Ochieng Omengo, F., Geeraert, N., Deirmendjian, L., Polsenaere, P., and Borges, A. V.: Technical Note: Large overestimation of $p \mathrm{CO}_{2}$ calculated from $\mathrm{pH}$ and alkalinity in acidic, organic-rich freshwaters, Biogeosciences, 12, 67-78, https://doi.org/10.5194/bg-12-67-2015, 2015.

Albéric, P., Pérez, M. A. P., Moreira-Turcq, P., Benedetti, M., Bouillon, S., and Abril, G.: Variation of dissolved organic carbon isotopic composition during the runoff cycle in the Amazon River and floodplains, CR Geosci., 350, 65-75, 2018.

Allen, G. H. and Pavelsky, T. M.: Global extent of rivers and streams, Science, 28, eaat0636, https://doi.org/10.1126/science.aat0636, 2018.

Aufdenkampe, A. K., Mayorga, E., Raymond, P. A., Melack, J. M., Doney, S. C., Alin, S. R., Aalto, R. E., and Yoo, K.: Rivers key to coupling biogeochemical cycles between land, oceans and atmosphere, Front. Ecol. Environ., 9, 53-60, 2011.

Bastviken, D., Tranvik, L., Downing, J. A., Crill, P. M., and Enrich-Prast, A.: Freshwater methane emissions offset the continental carbon sink, Science, 331, 50, https://doi.org/10.1126/science.1196808, 2011.

Battin, T. J., Kaplan, L. A., Findlay, S., Hopkinson, C. S., Marti, E., Packman, A. I., Newbold, J. D., and Sabater, F.: Biophysical controls on organic carbon fluxes in fluvial networks, Nat. Geosci., 2, 595-595, 2008.

Battin, T. J., Luyssaert, S., Kaplan, L. A., Aufdenkampe, A. K., Richter, A., and Tranvik, L. J.: The boundless carbon cycle, Nat. Geosci., 2, 598-600, 2009.

Bedford, B. L., Bouldin, D. R., and Beliveau, B.: Net oxygen and carbon dioxide balances in solutions bathing roots of wetland plants, J. Ecol., 79, 943-959, 1991.

Billett, M. F., Garnett, M. H., and Harvey, F.: UK peatland streams release old carbon dioxide to the atmosphere and young dis- 
solved organic carbon to rivers, Geophys. Res. Lett., 34, L23401, https://doi.org/10.1029/2007GL031797, 2007.

Bloom, A. A., Palmer, P. I., Fraser, A., Reay, D., and Frankenberg, C.: Methanogenesis Inferred from Methane and Gravity Spaceborne Data, Science, 327, 322-325, 2010.

Bontemps, S., Defourny, P., Van Bogaert, E., Arino, O., Kalogirou, V., Ramos Perez, J. J.: GLOBCOVER 2009 Products description and validation report. Université catholique de Louvain (UCL) \& European Space Agency (esa), Vers. 2.2, 53 pp., hdl:10013/epic.39884.d016, 2011.

Borges, A. V., Darchambeau, F., Teodoru, C. R., Marwick, T. R., Tamooh, F., Geeraert, N., Omengo, F. O., Guérin, F., Lambert, T., Morana, C., Okuku, E., and Bouillon, S.: Globally significant greenhouse gas emissions from African inland waters, Nat. Geosci., 8, 637-642, 2015a.

Borges, A. V., Abril, G., Darchambeau, F., Teodoru, C. R., Deborde, J., Vidal, L. O., Lambert, T., and Bouillon, S.: Divergent biophysical controls of aquatic $\mathrm{CO}_{2}$ and $\mathrm{CH}_{4}$ in the World's two largest rivers, Sci. Rep.-UK, 5, 15614, https://doi.org/10.1038/srep15614, 2015 b.

Bouchez, J., Gaillardet, J., Lupker, M., Louvat, P., France-Lanord, C., Maurice, L., Armijos, E., and Moquet, J.-S.: Floodplains of large rivers: weathering reactors or simple silos?, Chem. Geol., 332-333, 166-184, 2012.

Bridgham, S. D., Moore, T. R., Richardson, C. J., and Roulet, N. T.: Errors in greenhouse forcing and soil carbon sequestration estimates in freshwater wetlands: a comment on Mitsch et al. (2013), Landscape Ecol., 29, 1481-1485, 2014.

Butman, D. and Raymond, P. A.: Significant efflux of carbon dioxide from streams and rivers in the United States, Nat. Geosci., 4, 839-842, 2011.

Byrnes, B. H., Austin, E. R., and Tays, B. K.: Methane emissions from flooded rice soils and plants under controlled conditions, Soil Biol. Biochem., 27, 331-339, 1995.

Chanton, J. P. and Whiting, G.: Trace gas exchange in freshwater and coastal marine systems: ebullition and plant transport, in: Methods in Ecology: Biogenic Trace Gases: Measuring Emissions from Soil and Water, edited by: Matson, P. and Harriss, R., 98-125, Blackwell Scientific, Cambridge, MA, 1995.

Chapin III, F. S., Woodwell, G. M., Randerson, J. T., Rastetter, E. B., Lovett, G. M., Baldocchi, D. D., Clark, D. A., Harmon, M. E., Schimel, D. S., Valentini, R., Wirth, C., Aber, J. D., Cole, J. J., Goulden, M. L., Harden, J. W., Heimann, M., Howarth, R. W., Matson, P. A., McGuire, A. D., Melillo, J. M., Mooney, H. A., Neff, J. C., Houghton, R. A., Pace, M. L., Ryan, M. G., Running, S. W., Sala, O. E., Schlesinger, W. H., and Schulze, E.-D.: Reconciling Carbon-cycle Concepts, Terminology, and Methods, Ecosystems, 9, 1041-1050, 2006.

Ciais, P., Borges, A. V., Abril, G., Meybeck, M., Folberth, G., Hauglustaine, D., and Janssens, I. A.: The impact of lateral carbon fluxes on the European carbon balance, Biogeosciences, 5, 1259-1271, https://doi.org/10.5194/bg-5-1259-2008, 2008.

Ciais, P., Sabine, C., Bala, G., Bopp, L., Brovkin, V., Canadell, J., Chhabra, A., DeFries, R., Galloway, J., Heimann, M., Jones, C., Le Quéré, C., Myneni, R. B., Piao, S., and Thornton, P.: Carbon and Other Biogeochemical Cycles, in: Climate Change 2013: The Physical Science Basis. Contribution of Working Group I to the Fifth Assessment Report of the Intergovernmental Panel on Climate Change, edited by: Stocker, T. F., Qin, D., Plattner, G.-
K., Tignor, M., Allen, S. K., Boschung, J., Nauels, A., Xia, Y., Bex, V., and Midgley, P. M., Cambridge University Press, Cambridge, UK and New York, NY, USA, 2013.

Clark, J. M., Lane, S. N., Chapman, P. J., and Adamson, J. K.: Link between DOC in near surface peat and stream water in an upland catchment, Sci. Total Environ., 404, 308-315, 2008.

Cole, J. J. and Caraco, N. F.: Carbon in catchments: connecting terrestrial carbon losses with aquatic metabolism, Mar. Freshwater Res., 52, 101-110, 2001.

Cole, J. J., Caraco, N. F., Kling, G. W., and Kratz, T. K.: Carbon dioxide supersaturation in the surface waters of lakes, Science, 265, 1568-1570, 1994

Cole, J. J., Pace, M. L., Carpenter, S. R., and Kitchell, J. F.: Persistence of net heterotrophy in lakes during nutrient addition and food web manipulations, Limnol. Oceanogr., 45, 1718-1730, 2000.

Cole, J. J., Prairie, Y. T., Caraco, N. F., McDowell, W. H., Tranvik, L. J., Striegl, R. G., Duarte, C. M., Kortelainen, P., Downing, J. A., Middelburg, J. J., and Melack, J.: Plumbing the Global Carbon Cycle: Integrating Inland Waters into the Terrestrial Carbon Budget, Ecosystems, 10, 171-184, 2007.

Davidson, E. A., Richardson, A. D., Savage, K. E., and Hillinger, D. Y.: A distinct seasonal pattern of the ratio of soil respiration to total ecosystem respiration in a spruce-dominated forest, Glob. Change Biol., 12, 230-239, 2006.

Davidson, E. A., Figueiredo, R. O., Markewitz, D., and Aufdenkampe, A. K.: Dissolved $\mathrm{CO}_{2}$ in small catchment streams of eastern Amazonia: A minor pathway of terrestrial carbon loss, J. Geophys. Res., 115, G04005, https://doi.org/10.1029/2009JG001202, 2010.

Deirmendjian, L. and Abril, G.: Carbon dioxide degassing at the groundwater-stream-atmosphere interface: isotopic equilibration and hydrological mass balance in a sandy watershed, J. Hydrol., 558, 129-143, 2018.

Deirmendjian, L., Loustau, D., Augusto, L., Lafont, S., Chipeaux, C., Poirier, D., and Abril, G.: Hydro-ecological controls on dissolved carbon dynamics in groundwater and export to streams in a temperate pine forest, Biogeosciences, 15, 669-691, https://doi.org/10.5194/bg-15-669-2018, 2018.

Del Giorgio, P. A., Cole, J. J., Caraco, N. F., and Peters, R. H.: Linking planktonic biomass and metabolism to net gas fluxes in northern temperate lakes, Ecology, 80, 1422-1431, 1999.

Downing, J. A.: Plenary lecture Global limnology: up-scaling aquatic services and processes to planet Earth, Verh. Int. Verein. Limnol., 30, 1149-1166, 2009.

Engle, D. L., Melack, J. M., Doyle, R. D., and Fisher, T. R.: High rates of net primary production and turnover of floating grasses on the Amazon floodplain: implications for aquatic respiration and regional $\mathrm{CO}_{2}$ flux, Glob. Change Biol., 14, 369-381, 2008.

Freeman, C., Evans, C. D., and Monteith, D. T.: Export of organic carbon from peat soils, Nature, 412, 785, https://doi.org/10.1038/35090628, 2001.

Foster-Martinez, M. R. and Variano, E. A.: Air-water gas exchange by waving vegetation stems, J. Geophys. Res.-Biogeo., 121, 1916-1923, https://doi.org/10.1002/2016JG003366, 2016.

Garrels, R. M. and Mackenzie, F. T.: Evolution of Sedimentary Rocks, 397 pp., W. W. Norton, New York, 1971.

Geeraert, N., Omengo, F. O., Borges, A. V., Govers, G., and Bouillon, S.: Shifts in the carbon dynamics in a tropical 
lowland river system (Tana River, Kenya) during flooded and non-flooded conditions, Biogeochemistry, 132, 141-163, https://doi.org/10.1007/s10533-017-0292-2, 2017.

Haase, K. and Rätsch, G.: The Morphology and Anatomy of Tree Roots and Their Aeration Strategies, in: Amazonian Floodplain Forests: Ecophysiology, Biodiversity and Sustainable Management, edited by: Junk, W. J., Piedade, M. T. F., Wittmann, F., Schöngart, J., and Parolin, P., 142-160, Springer, 2010.

Hamilton, S. K., Sippel, S. J., and Melack, J. M.: Oxygen depletion and carbon dioxide and methane production in waters of the Pantanal wetland of Brazil, Biogeochemistry, 30, 115-141, 1995.

Hartmann, J., Lauerwald, R., and Moosdorf, N.: A Brief Overview of the GLObal RIver Chemistry Database, GLORICH, Proced. Earth Plan. Sc., 10, 23-27, 2014.

Heimann, M. and Reichstein, M.: Terrestrial ecosystem carbon dynamics and climate feedbacks, Nature, 451, 289-292, 2008.

Ho, D. T., Engel, V. C., Ferrón, S., Hickman, B., Choi, J., and Harvey, J. W.: On Factors Influencing Air-Water Gas Exchange in Emergent Wetlands, J. Geophys. Res.-Biogeo., 123, 178-192, https://doi.org/10.1002/2017JG004299, 2018.

Holgerson, M. A. and Raymond, P. A.: Large contribution to inland water $\mathrm{CO}_{2}$ and $\mathrm{CH}_{4}$ emissions from very small ponds, Nat. Geosci., 9, 222-226, 2016.

Hotchkiss, E. R., Hall Jr., R. O., Sponseller, R. A., Butman, D., Klaminder, J., Laudon, H., Rosvall, M., and Karlsson, J.: Sources of and processes controlling $\mathrm{CO}_{2}$ emissions change with the size of streams and rivers, Nat. Geosci., 8, 696-699, 2015.

Jenerette, G. D. and Lal, R.: Hydrologic sources of carbon cycling uncertainty throughout the terrestrial-aquatic continuum, Glob. Change Biol., 11, 1873-1882, 2005.

Johnson, M. S., Lehmann, J., Riha, S. J., Krusche, A. V., Richey, J. E., Ometto, J. P. H. B., and Guimaraes Couto, E.: $\mathrm{CO}_{2}$ efflux from Amazonian headwater streams represents a significant fate for deep soil respiration, Geophys. Res. Lett., 35, L17401, https://doi.org/10.1029/2008GL034619, 2008.

Jones, M. B. and Humphries, S. W.: Impacts of the $\mathrm{C}_{4}$ sedge Cyperus papyrus $\mathrm{L}$. on carbon and water fluxes in an African wetland, Hydrobiol., 488, 107-113, 2002.

Junk, W. J.: The Amazon Floodplain - a sink or source for organic carbon, in: Mitt. Geol. Paleont. Inst. Univ. Hamburg, SCOPE/UNEP Sonderband Heft 58, 287-293, 1985.

Junk, W. J., Piedade, M. T. F., Parolin, P., Wittmann, F., and Schöngart, J.: Ecophysiology, Biodiversity and Sustainable Management of Central Amazonian Floodplain Forests: A Synthesis, in: Amazonian Floodplain Forests: Ecophysiology, Biodiversity and Sustainable Management, edited by: Junk, W. J., Piedade, M. T. F., Wittmann, F., Schöngart, J., and Parolin, P., 511-540, Springer, 2010.

Juutinen, S., Alm, J., Larmola, T., Huttunen, J. T., Morero, M., Martikainen, P. J., and Silvola, J.: Major implication of the littoral zone for methane release from boreal lakes, Global Biogeochem. Cy., 17, 1117, https://doi.org/10.1029/2003GB002105, 2003.

Kindler, R., Siemens, J., Kaiser, K., Walmsley, D. C., Bernhofer, C., Buchmann, N., Cellier, P., Eugster, W., Gleixner, G., Grünwald, T., Heim, A., Ibrom, A., Jones, S., Jones, M., Klumpp, K., Kutsch, W. L., Steenberg Larsen, K., Lehuger, S., Loubet, B., Mckenzie, R., Moors, E., Osborne, B., Pilegaard, K., Rebmann, C., Saunders, M., Schmidt, M., Schrumpf, M., Seyfferth J., Skiba U. M., Soussana, J.-F., Sutton M. A., Tefs, C., Vowinckel, B.,
Zeeman, M., and Kaupenjohann M.: Dissolved carbon leaching from soil is a crucial component of the net ecosystem carbon balance, Glob. Change Biol., 17, 1167-1185, 2011.

Knoll, M. A. and James, W. C.: Effect of the advent and diversification of vascular land plants on mineral weathering through geologic time, Geology, 15, 1099-1102, 1987.

Lauerwald, R., Laruelle, G. G., Hartmann, J., Ciais, P., and Regnier, P. A. G.: Spatial patterns in $\mathrm{CO}_{2}$ evasion from the global river network, Global Biogeochem. Cy., 29, 534-554, https://doi.org/10.1002/2014GB004941, 2015.

Lauerwald, R., Regnier, P., Camino-Serrano, M., Guenet, B., Guimberteau, M., Ducharne, A., Polcher, J., and Ciais, P.: ORCHILEAK (revision 3875): a new model branch to simulate carbon transfers along the terrestrial-aquatic continuum of the Amazon basin, Geosci. Model Dev., 10, 3821-3859, https://doi.org/10.5194/gmd-10-3821-2017, 2017.

Lehner, B. and Döll, P.: Development and validation of a global database of lakes, reservoirs and wetlands, J. Hydrol., 296, 1-22, 2004.

Lin, H.: Earth's Critical Zone and hydropedology: concepts, characteristics, and advances, Hydrol. Earth Syst. Sci., 14, 25-45, https://doi.org/10.5194/hess-14-25-2010, 2010.

Lovett, G. M., Cole, J. J., and Pace, M. L.: Is Net Ecosystem Production Equal to Ecosystem Carbon Accumulation?, Ecosystems, 9, 1-4, 2006.

Lu, W., Xiao, J., Liu, F., Zhang, Y., Liu, C., and Lin, G.: Contrasting ecosystem $\mathrm{CO}_{2}$ fluxes of inland and coastal wetlands: a metaanalysis of eddy covariance data, Glob. Change Biol., 23, 11801198, https://doi.org/10.1111/gcb.13424, 2016.

Luyssaert, S., Ciais, P., Piao, S., Schulze, E.-D., Jung, M., Zaehle, S., Reichstein, M., Churkina, G., Papale, D., Abril, G., Beer, C., Grace, J., Loustau, D., Matteucci, G., Magnani, F., Schelhaas, M.-J., Nabuurs, G.-J., Verbeeck, H., Sulkava, M., van der Werf, G., and Janssens, I.: The European carbon balance revisited. Part 3: forests, Glob. Change Biol., 16, 1429-1450, 2010.

Mayorga, E., Aufdenkampe, A. K., Masiello, C. A., Krusche, A. V., Hedges, J. I., Quay, P. D., Richey, J. E., and Brown, T. A.: Young organic matter as a source of carbon dioxide outgassing from Amazonian rivers, Nature, 436, 538-541, 2005.

McDonald, C. P., Stets, E. G., and Striegl, R. G. B. D.: Inorganic carbon loading as a primary driver of dissolved carbon dioxide concentrations in lakes and reservoirs of the contiguous United States, Global Biogeochem. Cy., 27, 285-295, 2013.

Melack, J. M. and Hess, L. L.: Remote sensing of the distribution and extent of wetlands in the Amazon basin, in: Amazonian Floodplain Forests: Ecophysiology, Biodiversity and Sustainable Management, edited by: Junk, W. J., Piedade, M. T. F., Wittmann, F., Schöngart, J., and Parolin, P., 43-59, Springer, 2010.

Melack, J. M., Hess, L. L., Gastil, M., Forsberg, B. R., Hamilton, S. K., Lima, I. B. T., and Novo, E. M. L. M.: Regionalization of methane emissions in the Amazon Basin with microwave remote sensing, Glob. Change Biol., 10, 530-544, 2004.

Meybeck, M.: Carbon, nitrogen, and phosphorus transport by world rivers, Am. J. Sci., 282, 401-450, 1982.

Meybeck, M., Dürr, H. H., and Vörösmarty, C. J.: Global coastal segmentation and its river catchment contributors: A new look at land-ocean linkage, Global Biogeochem. Cy., 20, GB1S90, https://doi.org/10.1029/2005GB002540, 2006. 
Mitsch, W. J., Bernal, B., Nahlik, A. M., Mander, Ü., Zhang, L., Anderson, C. J., Jørgensen, S. E., and Brix, H.: Wetlands, carbon, and climate change, Landscape Ecol., 28, 583-597, 2013.

Morison, J. I. L., Piedade, M. T. F., Muller, E., Long, S. P., Junk, W. J., and Jones, M. B.: Very high productivity of the $\mathrm{C}_{4}$ aquatic grass Echinochloa polystachya in the Amazon floodplain confirmed by net ecosystem $\mathrm{CO}_{2}$ flux measurements, Oecologia, $125,400-411,2000$.

Mortillaro, J. M., Abril, G., Moreira-Turcq, P., Sobrinho, R., Pérez, M., and Meziane, T.: Fatty acid and stables isotopes $\left(\delta^{13} \mathrm{C}, \delta^{15} \mathrm{~N}\right)$ signatures of particulate organic matter in the Lower Amazon River: seasonal contrasts and connectivity between floodplain lakes and the mainstem, Org. Geochem., 42, 1159-1168, 2011.

Mulholland, P. J. and Kuenzler, E. J.: Organic carbon export from upland and forested wetland watersheds, Limnol. Oceanogr., 24, 960-966, 1979.

Nakhavali, M., Friedlingstein, P., Lauerwald, R., Tang, J., Chadburn, S., Camino-Serrano, M., Guenet, B., Harper, A., Walmsley, D., Peichl, M., and Gielen, B.: Representation of dissolved organic carbon in the JULES land surface model (vn4.4_JULES-DOCM), Geosci. Model Dev., 11, 593-609, https://doi.org/10.5194/gmd-11-593-2018, 2018.

Oldham, C. E., Farrow, D. E., and Peiffer, S.: A generalized Damköhler number for classifying material processing in hydrological systems, Hydrol. Earth Syst. Sci., 17, 1133-1148, https://doi.org/10.5194/hess-17-1133-2013, 2013.

Pan, Y., Birdsey, R. A., Fang, J., Houghton, R., Kauppi, P. E., Kurz, W. A., Phillips, O. L., Shvidenko, A., Lewis, S. L., Canadell, J. G., Ciais, P., Jackson, R. B., Pacala, S. W., McGuire, A. D., Piao, S., Rautiainen, A., Sitch, S., and Hayes, D.: A large and persistent carbon sink in the world's forests, Science, 333, 988-993, 2011.

Papa, F., Prigent, C., Aires, F., Jimenez, C., Rossow, W. B., and Matthews, E.: Interannual variability of surface water extent at the global scale, 1993-2004, J. Geophys. Res., 115, D12111, https://doi.org/10.1029/2009JD012674, 2010.

Parolin, P., Junk, W. J., and Piedade, M. T. F.: Gas exchange of six tree species from Central Amazonian floodplains, Trop. Ecol., 42, 15-24, 2001.

Peixoto, R. B., Marotta, H., Bastviken, D., Enrich-Prast, A.: Floating Aquatic Macrophytes Can Substantially Offset Open Water $\mathrm{CO}_{2}$ Emissions from Tropical Floodplain Lake Ecosystems, Ecosystems, 19, 724-736, 2016.

Piedade, M. T. F., Long, S. P., and Junk, W. J.: Leaf and canopy photosynthetic $\mathrm{CO}_{2}$ uptake of a stand of Echinochloa polystachya on the Central Amazon floodplain. Are the high potential rates associated with the $\mathrm{C}_{4}$ syndrome realized under the near-optimal conditions provided by this exceptional natural habitat?, Oecologia, 97, 193-201, 1994.

Piedade, M. T. F., Ferreira, C. S., de Oliveira Wittmann, A., Buckeridge, M., and Parolin, P.: Biochemistry of Amazonian Floodplain Trees. in Amazonian floodplain forests: ecophysiology, biodiversity and sustainable management, edited by: Junk, W. J., Piedade, M. T. F., Wittmann, F., Schöngart, J. and Parolin, P., 127-139, Springer, 2010.

Pierobon, E., Bolpagni, R., Bartoli, M., and Viaroli, P.: Net primary production and seasonal $\mathrm{CO}_{2}$ and $\mathrm{CH}_{4}$ fluxes in a Trapa natans L. meadow, J. Limnol., 69, 225-234, 2010.
Prairie, Y. T., Bird, D. F., and Cole, J. J.: The summer metabolic balance in the epilimnion of southeastern Quebec lakes, Limnol. Oceanogr., 47, 316-321, 2002.

Prigent, C., Matthews, E., Aires, F., and Rossow, W. B.: Remote sensing of global wetland dynamics with multiple satellite data sets, Geophys. Res. Lett., 28, 4631-4634, 2001.

Prigent, C., Papa, F., Aires, F., Rossow, W. B., and Matthews, E.: Global inundation dynamics inferred from multiple satellite observations, 1993-2000, J. Geophys. Res., 112, D12107, https://doi.org/10.1029/2006JD007847, 2007.

Quay, P. D., Wilbur, D. O., Richey, J. E., Hedges, J. I., Devol, A. H., and Victoria, R.: Carbon cycling in the Amazon River: Implications from the ${ }^{13} \mathrm{C}$ compositions of particles and solutes, Limnol. Oceanogr., 37, 857-871, 1992.

Raymond, P. A., Hartmann, J., Lauerwald, R., Sobek, S., McDonald, C., Hoover, M., Butman, D., Striegl, R., Mayorga, E., Humborg, C., Kortelainen, P., Dürr, H., Meybeck, M., Ciais, P., and Guth, P.: Global carbon dioxide emissions from inland waters, Nature, 503, 355-359, 2013.

Reichstein, M., Bahn, M., Ciais, P., Frank, D., Mahecha, M. D., Seneviratne, S. I., Zscheischler, J., Beer, C., Buchmann, N., Frank, D. C., Papale, D., Rammig, A., Smith, P., Thonicke, K., van der Velde, M., Vicca, S., Walz, A., and Wattenbach, M.: Climate extremes and the carbon cycle, Nature, 500, 287-295, 2013.

Ribaudo, C., Bartoli, M., Longhi, D., Castaldi, S., Neubauer, S. C., and Viaroli, P.: $\mathrm{CO}_{2}$ and $\mathrm{CH}_{4}$ fluxes across a Nuphar lutea (L.) Sm. Stand., J. Limnol., 71, 200-210, 2012.

Richey, J. E., Melack, J. M., Aufdenkampe, A. K., Ballester, V. M., and Hess, L.: Outgassing from Amazonian rivers and wetlands as a large tropical source of atmospheric $\mathrm{CO}_{2}$, Nature, 416, 617620, 2002.

Ryan, M. G. and Law, B. E.: Interpreting, measuring, and modeling soil respiration, Biogeochemistry, 73, 3-27, 2005.

Saunders, M. J., Jones, M. B., and Kansiime, F.: Carbon and water cycles in tropical papyrus wetlands, Wetl. Ecol. Manag., 15, 489498, 2007.

Saunois, M., Bousquet, P., Poulter, B., Peregon, A., Ciais, P., Canadell, J. G., Dlugokencky, E. J., Etiope, G., Bastviken, D., Houweling, S., Janssens-Maenhout, G., Tubiello, F. N., Castaldi, S., Jackson, R. B., Alexe, M., Arora, V. K., Beerling, D. J., Bergamaschi, P., Blake, D. R., Brailsford, G., Brovkin, V., Bruhwiler, L., Crevoisier, C., Crill, P., Covey, K., Curry, C., Frankenberg, C., Gedney, N., Höglund-Isaksson, L., Ishizawa, M., Ito, A., Joos, F., Kim, H.-S., Kleinen, T., Krummel, P., Lamarque, J.-F., Langenfelds, R., Locatelli, R., Machida, T., Maksyutov, S., McDonald, K. C., Marshall, J., Melton, J. R., Morino, I., Naik, V., O'Doherty, S., Parmentier, F.-J. W., Patra, P. K., Peng, C., Peng, S., Peters, G. P., Pison, I., Prigent, C., Prinn, R., Ramonet, M., Riley, W. J., Saito, M., Santini, M., Schroeder, R., Simpson, I. J., Spahni, R., Steele, P., Takizawa, A., Thornton, B. F., Tian, H., Tohjima, Y., Viovy, N., Voulgarakis, A., van Weele, M., van der Werf, G. R., Weiss, R., Wiedinmyer, C., Wilton, D. J., Wiltshire, A., Worthy, D., Wunch, D., Xu, X., Yoshida, Y., Zhang, B., Zhang, Z., and Zhu, Q.: The global methane budget 2000-2012, Earth Syst. Sci. Data, 8, 697-751, https://doi.org/10.5194/essd-8-697-2016, 2016.

Sawakuchi, H. O., Neu, V., Ward, N. D., Barros, M. L. C., Valerio, A. M., Gagne-Maynard, W., Cunha, A. C., Less, D. F. S., Diniz, J. E. M., Brito, D. C., Krusche, A. V., and Richey, J. E.: Carbon 
Dioxide Emissions along the Lower Amazon River, Front. Mar. Sci., 21, 76, https://doi.org/10.3389/fmars.2017.00076, 2017.

Schwalm, C. R., Williams, C. A., Schaefer, K., Anderson, R., Arain M. A., Baker, I., Barr, A., Black, T. A., Chen, G., Chen, J. M., Ciais, P., Davis, K. J., Desai, A., Dietze, M., Dragoni, D., Fischer, M. L., Flanagan, L. B., Grant, R., Gu, L., Hollinger, D., Izaurralde, R. C., Kucharik, C., Lafleur, P., Law, B. E., Li, L., Li, Z., Liu, S., Lokupitiya, E., Luo, Y., Ma, S., Margolis, H., Matamala, R., McCaughey, H., Monson, R. K., Oechel, W. C., Peng, C., Poulter, B., Price, D. T., Riciutto, D. M., Riley, W., Sahoo, A. K., Sprintsin, M., Sun, J., Tian, H., Tonitto, C., Verbeeck, H., and Verma, S. B.: A model-data intercomparison of $\mathrm{CO}_{2}$ exchange across North America: Results from the North American Carbon Program site synthesis, J. Geophys. Res., 115, G00H05, https://doi.org/10.1029/2009JG001229, 2010.

Segarra, K. E. A., Schubotz, F., Samarkin, V., Yoshinaga, M. Y., Hinrichs, K.-U., and Joye, S. B.: High rates of anaerobic methane oxidation in freshwater wetlands reduce potential atmospheric methane emissions, Nat. Commun., 6, 7477, https://doi.org/10.1038/ncomms8477, 2015.

Sharifi, A., Kalin, L., Hantush, M. M., Isik, S., and Jordan, T. E.: Carbon dynamics and export from flooded wetlands: A modeling approach, Ecol. Model., 263, 196-210, 2013.

Sjögersten, S., Black, C. R., Evers, S., Hoyos-Santillan, J., Wright, E. L., and Turner, B. L.: Tropical wetlands: A missing link in the global carbon cycle?, Global Biogeochem. Cy., 28, 1371-1386, 2014.

Sobek, S., Tranvik, L. J., and Cole, J. J.: Temperature independence of carbon dioxide supersaturation in global lakes, Global Biogeochem. Cy., 19, GB2003, https://doi.org/10.1029/2004GB002264, 2005.

Stöckli, R., Lawrence, D. M., Niu, G.-Y., Oleson, K. W., Thornton, P. E., Yang, Z.-L., Bonan, G. B., Denning, A. S., and Running, S. W.: Use of FLUXNET in the Community Land Model development, J. Geophys. Res.-Biogeo., 113, G01025, https://doi.org/10.1029/2007JG000562, 2008.
Tian, H., Lu, C., Yang, J., Banger, K., Huntzinger, D. N., Schwalm, C. R., Michalak, A. M., Cook, R., Ciais, P., Hayes, D., Huang, M., Ito, A., Jain, A. K., Lei, H., Mao, J., Pan, S., Post, W. M., Peng, S., Poulter, B., Ren, W., Ricciuto, D., Schaefer, K., Shi, X., Tao, B., Wang, W., Wei, Y., Yang, Q., Zhang, B., and Zeng,N.: Global patterns and controls of soil organic carbon dynamics as simulated by multiple terrestrial biosphere models: Current status and future directions, Global Biogeochem. Cy. 29, 775-792, https://doi.org/10.1002/2014GB005021, 2015.

Tranvik, L. J., Downing, J. A., Cotner, J. B., Loiselle, S. A., Striegl, R. G., Ballatore, T. J., Dillon, P., Finlay, K., Fortino, K., Knoll, L. B., Kortelainen, P. L., Kutser, T., Larsen, S., Laurion, I., Leech, D. M., McCallister, S. L., McKnight, D. M., Melack, J. M., Overholt, E., Porter, J. A., Prairie, Y., Renwick, W. H., Roland, F., Sherman, B. S., Schindler, D. W., Sobek, S., Tremblay, A., Vanni, M. J., Verschoor, A. M., von Wachenfeldt, E., and Weyhenmeyer, G. A.: Lakes and reservoirs as regulators of carbon cycling and climate, Limnol. Oceanogr., 54, 2298-2314, 2009.

Tsypin, M. and Macpherson, G. L.: The effect of precipitation events on inorganic carbon in soil and shallow groundwater, Konza Prairie LTER Site, NE Kansas, USA, Appl, Geochem., 27, 2356-2369, 2012.

Vannote, R. L., Minshall, G. W., Cummins, K. W., Sedell, J. R., and Cushing, C. E.: River continuum concept, Can. J. Fish. Aquat. Sci., 37, 130-137, 1980.

Villa, P., Pinardi, M., Bolpagni, R., Gillier, J.-M., and Zinked, P.: Assessing macrophyte seasonal dynamics using dense time series of medium resolution satellite data, Remote Sens. Environ., 216, 230-244, 2018.

Ward, N. D., Keil, R. G., Medeiros, P. M., Brito, D., Cunha, A. C., Dittmar, T., Yager, P. L., Krusche, A. V., and Richey J. E.: Degradation of terrestrially derived macromolecules in the Amazon River, Nat. Geosci., 6, 530-533, 2013.

Wetzel, R. G.: Wetlands as metabolic gates, J. Great Lakes Res., 18, 529-532, 1992. 